\title{
THE BROADENED SCOPE OF SECTION 22 (a): THE EVOLUTION OF THE CLIFFORD DOCTRINE
}

\author{
EDMUND W. PAVENSTEDT†
}

During the year 1940 the Supreme Court closed two broad avenues freely utilized in the past by those who sought to minimize their surtaxes. Until then it had been thought that trust income was taxable to a settlor only in situations covered by specific sections of the revenue statutes. ${ }^{1}$ As to assigned income, although there was a conflict in the lower courts, ${ }^{2}$ the prevailing view tended to regard the assignor as not liable to a tax thereon if his right to receive the income had become fixed prior to the time of the assignment. In Helecring a: Clifford ${ }^{3}$ the Court ruled that the head of a family could not affect his tax liability by allocating part of his income among his wife or children through the medium of a short-term trust over the corpus of which he retained substantial control; in such a case the trust income, even though not used to satisfy any legal obligation of the grantor. ${ }^{2}$ remained taxable to him. In Helvering $v$. Horst ${ }^{\mathbb{5}}$ and Helvering $v$. Eubank ${ }^{\mathfrak{6}}$ it was held that taxation of income which a person has a fixed right to receive without further efforts on his part cannot be avoided by an assignment made prior to the time when such income becomes due and payable.

To reach these conclusions the Court had recourse to a new and expanded interpretation of the definition of "gross income" contained in Section 22(a) of the Revenue Act." In the Clifford case the broad

$\uparrow$ Chief, Securities Association Unit, Securities and Exchange Commission. Formerly Special Assistant to the Attorney General, Tax Division, Department of Justice.

1. Sections dealing with revocable trusts and trusts for the benefit of the grantor appear as $\$ \$ 219(\mathrm{~g})$ and $(\mathrm{h})$ in the 1924 and 1926 Revenue Acts, and as $\$ \$ 166$ and 167 in subsequent Acts and in the Internal Revenue Code. The amendments engraitcd from time to time reflect the legislative aspect of the endeavor to keep pace with thoss unwilling to contribute their due share to the Treasury.

2. Compare such cases as Hall v. Burnet, 54 F. (2d) 443 (App. D. C. 1931), ceri. denied, 285 U. S. 552 (1932), with Parker v. Routzahn, 56 F. (2d) 730 (C. C. A. Gth, 1932), cert. denied, 287 U. S. 606 (1932). See also infra notes 143-45.

3. 309 U. S. 331 (Feb. 26, 1940).

4. Had it been so used, it would have been tasable to the grantor in any event under the line of cases beginning with Douglas v. Willcuts, 296 U. S. 1 (1935).

5. 311 U. S. 112 (Nov. 25, 1940).

6. 311 U. S. 122 (Nov. 25, 1940).

7. The wording of this section, insofar as relevant to the cases discussed in this article, has remained substantially the same in all the Revenue Acts. It now appears in the Internal Revenue Code as follows: "Gross Income Defined. (a) 'Gross income' includes gains, profits, and income derived from salaries, wages, or compensation for personal service, ... of whatever kind and in whatever form paid, or from professions, vocations, trades, businesses, commerce, or sales, or dealings in property, whether 
sweep of that section's language was construed to indicate Congressional purpose to use the full measure of the taxing power. One of the categories of "gross income" is there defined as "income derived from dealings in property, whether real or personal, growing out of the ownership or use of or interest in such property." Presumably this category was in the mind of the Court when it stated the issue of the Clifford case to be "whether the grantor after the trust has been established may still be treated, under this statutory scheme, as the owner of the corpus."

In the first of the current assignment of income cases $^{8}$ another category was relied upon, namely, "income derived from wages, or compensation for personal service, of whatever kind and in whatever form paid; also from interest." The Court stated the clominant purpose of the revenue laws was taxation of income to that individual who earns or otherwise creates the right to receive it and enjoy the benefit of it when paid. Such benefit was equally enjoyed, the Court held, when he who is entitled to receive income derived from interest or compensation makes use of his power to dispose of it in procuring satisfactions which he would otherwise procure only by the use of the money when received.

In Harrison v. Schaffner, ${ }^{\circ}$ another case involving assignment of income, the Court summarized the rationale underlying the decisions in both the trust income and the assignment cases. It stated that provisions like Section 22(a) have uniformly been construed as "not so mitch concerned with the refinements of title as with the actual command over the income which is taxed and the actual benefit for which the tax is paid." The Clifford, Horst and Eubank cases were among those cited in support of this statement. The Court continued:

"It was for that reason that in each of those cases it was held that one vested with the right to receive income did not escape the tax by any kind of anticipatory arrangement, however skilfully devised, by which he procures payment of it to another, since, by the exercise of his power to command the income, he enjoys the benefit of the income on which the tax is laid." 10

Thus it appears that, for purposes of discussion, the two types of cases ought not to be pigeonholed separately. The tax practitioner must weigh the implications of decisions involving both when considering a

real or personal, growing out of the ownership or use of or interest in such property; also from interest, rent, dividends, securities, or the transaction of any business carried on for gain or profit, or gains or profits and income derived from any source what= ever..."

8. Helvering v. Horst, 311 U. S. 112 (1940).

9. 312 U. S. 579 (March 31, 1941).

10. Italics supplied. 312 U. S. 579,582 (1941). 
problem connected with either. Yet it seems convenient to treat them separately in this article, especially because during the last year and a half so many Board of Tax Appeals and lower court decisions have wrestled ${ }^{11}$ with numerous widely varying fact situations, all of which have presented the problem whether the settlor of a trust should, for income tax purposes, be treated as still the owner of the corpus.

\section{The Cliffrord Case}

The provisions of the trust instrument involved in the Clifford case may be summarized as follows:

Trustee: The grantor.

Cestui: The grantor's wife.

Term: Five years, or less if either the grantor or his wife died.

Reversion: To grantor as to corpus, to the wife as to any accumulated income.

Income: All net income derived from ordinary cash dividends to be held for "exclusive benefit" of the cestui, all other income to be added to corpus.

Trustee's Powers:

1. To pay out or accumulate the income;

2. To manage the property with right

(a) to vote trusteed shares;

(b) to sell, exchange, mortgage or pledge securities constituting corpus or accumulated income on any terms or for any consideration;

(c) to invest cash constituting corpus or accumulated income by making even unsecured loans, 12 by deposits in banks, or by buying securities regardless of their speculative character, rate of return or legality for trust funds;

(d) to compromise any claims held as trustee;

(e) to hold trust property in any name, including his own as an individual.

Exculpatory Clause: Liable only for losses occasioned by wilful and deliberate breach of duties as trustee.

Limitations on Cestui: Neither principal nor future or accrued income to be liable for her debts; and she could not dispose of the income in any way until it was actually paid out.

11. The Board has very recently reiterated its observation that "there is some uncertainty as to the extent of the applicability of $\$ 22(\mathrm{a})$ under the decision of the Clifford case." Frederick Ayer, 3 C. C. H. 1941 Fed. Tax Serv. 17683 (B. T. A.).

12. The Court assumes that Clifford did not have power to make loans to himself, presumably because such a deviation from normal fiduciary conduct must be esplicitly authorized by the terms of the trust instrument. 309 U. S. 331, 335 (1940). See $1 \mathrm{RE}$ STATEZIENT, Trusts (1935) $\$ 170(1)$. 
With regard to the creation and operation of the trust, it was stipulated that "tax effects", though considered, were not the sole motive for setting up the trust; that the wife had other substantial income; that she was free to use, and did use, the trust income as she chose; that the trust was not created and did not operate to relieve the grantor from liability for family or household expenses; and that a gift tax was paid on the transfer.

The Court did not assail this trust as invalid under state law, ${ }^{13}$ but asserted that a device employing such a family arrangement to create an unreal number of economic units must be probed minutely to ascertain whether it was exempt from the federal income tax. And, according to the Court, the criterion to determine this under Section $22(a)$ was whether the grantor may still be treated as the owner of the corpus. It concluded that he continued to be its owner because (1) the income was only temporarily reallocated within the family group; (2) the wife being the recipient thereof, the grantor indirectly enjoyed its benefits; and (3) he retained such control over the corpus, particularly over its investment, that, with immaterial exceptions, his powers as trustee were equivalent to those which an individual would have had.

Viewed together in a realistic light, the factors of retained control and the indirect benefits were considered by the Court to leave the grantor in substantially the same economic position in which he was prior to the creation of the trust. Hence it held that the Board did not err when it found that the grantor remained the owner of the corpus for the purposes of Section 22(a).

The decision was followed by a flood of comment and criticism, as well as inquiry as to the scope of the newly announced rule. ${ }^{14}$ Most of

13. The Second Circuit's interpretation of the Clifford decision as holding the trust "valid under state law and [as] involving the relation of trustee and cestui que trust between the parties" [Commissioner v. Berolzheimer, 116 F. (2d) 628,630 (C. C. A. 2d, 1940)] seems more accurate than the Board's implication that the Court decmed Clifford's creation an "illusory trust." William J. Garland, 43 B. T. A. 731 (on rehearing, 1941).

14. Ray, The Income Tax on Short Term and Revocable Trusts (1940) 53 Hakv. L. Rev. 1322, 1348; Griswold, A Summary of the Regulations Problem (1941) 54 HAnv. L. Rev. 398, 421-22; Nash, What Lawe of Taxation? (1940) 9 FordHax L. Rev. 165, 188; Nash, Implications of Some Recent Developments in the Taxation of Trusts (1940) 18 Tax Mag. 267, 327; Tye, Federal Taxation of Irrevocable Trusts Recramined (1940) 18 Tax Mag. 216, 222; Surrey, The Supreme Court and the Federal Income Tax: Some Implications of the Recent Decisions (1941) 35 ILL. L. Rev. 779, 794; Magill, The Supreme Court on Federal Taxation, $1939-40$ (1940) 8 U. of CHI. L. Rev. 1, 5 ; Rudick, The Problem of Personal Income Tax Avoidance (1940) 7 Law \& Contemr. Pron. 243, 258; Altman, Commnnity Property in Peril (1941) 19 Tax Mag. 262; Paul, Srubuss in Federal Taxation, Third Series (1940) 200; Comment (1940) 38 Micir. L. Rev. 885; (1940) 53 Harv. L. Rev. 1050, (1940) 24 Minn. L. Rev. 1005, (1940) 49 Yal.E L. J. 1305. 
the adverse comment was bottomed on the proposition that a taxpayer is entitled to certainty when arranging his affairs and that it is inequitable to change the rules of the game by "judicial legislation" when certain methods for the deflection of income, not rendered nugatory by specific statutory provisions, have for some time been successfully used to minimize taxes. But has not the taxpayer blessed with large resources been advised quite definitely that if his net income amounts to $X$ dollars it will be subject to certain clearly stated surtax rates? Does not the law set forth with the utmost clarity the Congressional intent of taxing at increasing rates in accordance with ability to pay? And have not the courts for many years, except when confronted with some inescapable casus omissus s. $^{15}$ or statutory language so unequivocal as to require remedy through legislation, ${ }^{10}$ supplemented Congressional efforts at blocking attempts to thwart the purpose of successive taxing statutes ? $^{17}$

To be sure, as Mr. Justice Roberts points out in his dissent in the Clifford case, the Revenue Acts from the very beginning have provided for the separate treatment of trusts ${ }^{18}$ and, normally, for the taxability of trust income not to the grantor but to either the trustee or the beneficiary. ${ }^{19}$ Yet it is submitted that the term "trust" as used in these laws should in sood conscience be taken to mean a bona fide trust,"

15. See Smietaxka v. First Trust \& Sav. Bank, 257 U. S. 602 (1922); Third Scottish American Truct Co. v. United States, 37 F. Supp. 279, 282 (Ct. Cl., 1941); Helvering v. Bowen, 83 F. (2d) 926, 928 (C. C. A. 4th, 1936); Durr Drug Co. v. United States, 99 F. (2d) 757,759 (C. C. A. 5th, 1938).

16. See Shwab v. Doyle, 258 U. S. 529 (1922) ; Commissioner v. Morris, 90 F. (2d) 962 (C. C. A. 2d, 1937). Cf. Taft v. Commissioner, 304 U. S. 351, 359 (1938).

17. See Burnit v. Wells, 289 U. S. 670, 677 (1933); P.xxL, Studies in Fereral Taxation (1937) 61. But see Kent v. Rothensies, 35 F. Supp. 291, 295 (E. D. Pa. 1940), rev'd, 120 F. (2d) 476 (C. C. A. 3d, 1941), where the district court, in a case involving trust income which the Government deemed tasable to the grantor, noticed that Congress with respect to such income "was frequently concerned with tas avoidance, and from time to time amended the law to meet cases which evisting statutes were inadequate to reach." This, however, continues the opinion, "is no warrant for this court to take over the task of catching up with the taxpayer."

18. In Kent v. Rothensies, 35 F. Supp. 291, 295 (E. D. Pa. 1940), rev'd, 120 F. (2d) 476 (C. C. A. 3d, 1941), the district court insisted that Congress has shown no intention to disregard the trust entity but on the contrary has carefully preserved and defined it as a subject of taxation; the opinion sounds like an echo of Mrr. Justice Rob. erts' dissent in the Clifford case.

19. Note that the minority fought the whole trend exemplified by the "Section 22(a) cases" on the basis of statutory interpretation rather than on constitutional grounds. The Horst case certainly seems to go much farther than Burnet v. Wells, 289 U. S. $6 \% 0$ (1933). Perhaps Mr. Justice MIcReynolds, who wrote the dissent in the Horst case, felt that an argument based on constitutional grounds would have been a vain recherihe ds temps perdu. Cf. N. Y. Herald Tribune, Feb. 19, 1935, p. 1, col. 8, attributing to him the statement: "The Constitution is gone."

20. In DuPont v. Commissioner, 118 F. (2d) 544,545 (C. C. A. 3d, 1941), involving reciprocal sales and repurchases of securities by two friends who wished to establish 
an entity to which the settlor has transferred property completely and definitively. The fact that Congress has from time to time enacted certain provisions ${ }^{21}$ singling out for taxation to the grantor the income of several types of trusts, rather habitually used to circumvent its intent, cannot fairly be interpreted as an implied sanction of other trust arrangements whereby taxpayers have "contrived to keep the larger benefits of ownership and be relieved of the attendant burdens." 22 Indeed, Mr. Justice Douglas, who spoke for the majority in the Clifford case, might well have echoed a reported utterance of Judge Learned FIand:

"I have been violently criticized by the tax lawyers for having originated a revolutionary doctrine in the Gregory case, whereas all that I did was to note the plain intention of Congress which tax practitioners had preferred to ignore in order that they might be able to provide simple methods of tax avoidance for their clients." "as

And he might have added that the recent excoriation epitomized in the somewhat sarcastic title "What Law of Taxation?" 24 is even less justified than that hurled at Judge Hand since the holding of the Clifford case was foreshadowed rather suggestively ${ }^{25}$ some years ago by the alternative ground for decision in DuPont v. Commissioner. ${ }^{20}$

losses for income tax purposes, Judge Clark said, "The attachment of an artificial inportance to the fact of sale placed a powerful weapon in the hands of the taxpayer. In its selection of this arbitrary criterion, the Congress used the bare phrase 'sale or exchange.' . . . The courts filled in the outline with the obviously indicated bona fides." (italics supplied).

21. See note 1 supra.

22. Burnet v. Wells, 289 U. S. 670,676 (1933).

23. Paul, op. cit. supra note 14 , at 125 , n. 388.

24. Nash, loc. cit. supra note 14.

25. See Surrey, Assignments of Income and Related Devices: Choice of the Tarable Person (1933) 33 CoL. L. Rev. 791, 818, 826.

26. 289 U. S. 685 (1933). Here the Court unanimously held taxable to the grantor the income of a short-term trust where "the grantor did not divest himself of title in any permanent or definitive way, did not strip himself of every interest in the subject matter of the trust estate" (italics supplied). This decision was not followed by such adverse comment as was occasioned by the Clifford case, very probably because its im. portance was overlooked, attention being concentrated on Burnet $v$. W $\mathrm{W} / \mathrm{s}$, decided the same day. Or the explanation may be found in the fact that the alternative ground for decision was deemed to deal only with the constitutional power of Congress and the validity of $\S 219$ (h) of the 1924 and 1926 Revenue Acts [now INT. REv. CoDE $\S 167$ (a) (3) (1939) ] as applied to the state of facts presented by the DuPont case; but this view has not been accepted by one of the Board's oldest and ablest members. Sec Graham Sumner, 40 B. T. A. 811, 813 (1939), on appeal C. C. A. 2d. And in Benjamin F. Wollman, 31 B. T. A. 37 (1934), the Board held that "the general provisions of the statutes will support taxation of income to the grantor where he retains powers as broad as in this case." Cf. Ray, sitpra note 14, at 1345 . Parenthetically, it may be pointed out that Clifford created the trust which was to cause so much furore more than a year after the decision in the DuPont case was handed down. 
The inquiry as to the scope of the Clifford doctrine is understandable. Some commentators ${ }^{27}$ and courts $^{28}$ appear to assume that future decisions of the Court will set certain fairly precise limits beyond which a settlor may operate without fear of being swept into the embrace of Section 22(a). It is submitted that to follow such a course would rob the holding of its greatest element of strength, which is its very vagueness and elasticity. The Court has said to the taxpayer: "If you set up a trust so hedged about with restrictions that, as a practical matter, you still have most of the important powers which an outright owner possesses and feel no poorer as a result of the new creation, then the income remains taxable to you." This is a perfectly practical test the application of which will furnish a ready answer in most situations. In borderline situations, moreover, it does not seem unfair that the taxpayer should be expected to proceed at his peril since the result of his contriving, and probably in an overwhelming majority of instances the purpose as well, is to minimize surtaxes by creating two or more taxable entities in lieu of the pre-existing single entity which Congress intended to tax. Taxpayers have long been on notice that "anticipatory arrangements . . . however skilfully devised" ${ }^{29}$ are likely to come to grief. In view of the Court's well known attitude with respect to these arrangements, only an incurable optimist will expect a meticulous tracing of the frontiers bounding the applicability of the Clifford rule.

Such further intimations as the Court has given to date clearly indicate that it regards the concept underlying the Clifford decision as capable of great expansion rather than subject to limitation. Only two short-term trust cases have discussed the rule and then by way of dictum. But the trend of the Court's observations must have chilled the hopes of those who looked for a strict construction of the Clifford case. ${ }^{30}$

In Helvering v. Fuller ${ }^{31}$ a drastic extension of the Clifford rule was suggested. There the income of an alimony trust was held not taxable to the settlor for reasons immaterial to this discussion. The trust was to endure for ten years after which the property was to go outright

27. See, e.g., Magill, supra note 14 , at 5 .

28. White v. Higgins, 116 F. (2d) 312 (C. C. A. 1st, 1940); Commissioner v. O'Keeffe, 11S F. (2d) 639,642 (C. C. A. 1st, 1941) ("But the outer limits of the doctrine of Helvering v. Clifford have not yet been authoritatively determined.").

29. Lucas v. Earl, 281 U. S. 111 (1930).

30. But see Commissioner v. Branch, 114 F. (2d) 985 (C. C. A. 1st, 1940); Helvering v. Palmer, 115 F. (2d) 368 (C. C. A. 2d, 1940), aff'g, Carleton H. Palmer, 40 B. T. A. 1002 (1939) ; Kent v. Rothensies, 35 F. Supp. 291 (E. D. Pz. 1940), rez'd, 120 F. (2d) 476 (C. C. A. 3d, 1941) ; Arthur 11. Betts, 3 C. C. H. 1941 Fed. Tax Serv. II 7116-D (B. T. A. mem.); Jessie W. Donahue, 44 B. T. A. 329 (1941); Frederick Ayer, 3 C. C. H. 1941 Fed. Tax Serv. I 7683 (B. T. A.).

31. 310 U. S. 69 (1940). 
to the divorced wife. Although the Court did not pass on the applicability of the Clifford rule because the Government had not raised the point, Mr. Justice Douglas remarked that the trust agreement might have left the grantor with sufficient interest in or control over the trust to make him the owner of the corpus for income tax purposes. It may be predicted with some confidence that the Commissioner will not fail to take this broad hint that neither family solidarity, obviously no longer existent in the Fuller situation, nor the ultimate reversion of the trust corpus to the grantor, will be deemed by the Court factors indispensable to bring the income of a term trust within the Clifford rule. No dotubt these elements, where present, will continue to have a cumtlative effect when deciding the problem of ownership, but their absence will not of itself preclude a finding of ownership based on the all-important consideration of control..$^{32}$

The second decision, Hormel v. Helvering, ${ }^{33}$ intimated a somewhat startling broadening of the family solidarity concept. Although the Court did not consider the merits but remanded the case so that the taxpayer might have an opportunity to offer evidence on the isste raised by the Clifford rule, Mr. Justice Black thought the chances of taking the case out of the rule quite remote, saying:

"Here, as there, control over the trusts was completely in the hands of the taxpayer and his wife. For while petitioner's trust instruments showed a co-trustee acting with petitioner, the same instruments also disclosed that such co-trustee could be removed at any time by the joint action of petitioner and his wife." ${ }^{34}$

In this way the Court discounted the independent action of the wife in any removal of the co-trustee, thus indicating that in family trust cases it might consider one spouse the alter ego of the other (and, should it do so, a similar treatment of other close relatives would seem predictable). Such a conclusion, while perhaps a logical consequence of the Clifford case, goes far beyond the refusal of that decision "to treat the wife as a complete stranger." 35

32. But see Commissioner v. Chamberlain, 121 F. (2d) 765 (C. C. A. 2d, 1941) (income held not taxable to settlor because short-term trust lacked "family purpose flavor") ; accord, Maris J., dissenting in Commissioner v. Brown, 4 C. C. H. 1941 Fed. Tax Serv. $\{9667$ (C. C. A. 3d, 1941).

33. 312 U. S. 552 (1941). See (1940) 25 Wash. U. L. Q. 616, (1941) 50 Yale L. J. 1460.

34. 312 U. S. 552,559 (1941).

35. The Hormel case also indicates that the Court will make no distinction because retained powers of control are exercised by the grantor qua trustee, i.e., in a fiduciary capacity, a distinction relied upon in Carleton H. Palmer, 40 B. T. A. 1002 (1939), aff'd sub nom. Helvering v. Palmer, 115 F. (2d) 368 (C. C. A. 2d, 1940). Helvcring v. Richter, 312 U. S. 561 (1941), decided together with the Hormel case, dealt only with the question whether the Circuit Court of Appeals should have considered the applica- 
It may be argued that by the suggestions thrown out in the Hormel and Fuller opinions the Court has within the short space of one term already so expanded the Clifford rule as to render it unrecognizable and hence obsolete. It must be conceded that the principal factors stressed in the Clifford case as connoting continuing ownership probably will not serve as a reliable yardstick for anxious or potential trustors weighing the chances of possible unexpected tax liability. Yet a review of decisions on similar and related issues by lower tribunals since the Clifford decision may be of interest as reflecting their reaction thereto and presenting, by way of illustration, various new facets of the problem not touched upon in the principal case.

\section{Classification of Post-Cliffrokd Decisions}

A classification of the Board and court decisions which have applied or discussed the Clifford rule, both with regard to short term trusts and in cognate fields, can be made in various ways. Grouping the cases as those which follow, extend or refuse to apply the rationale of the Clifford case might serve, somewhat in the manner of a Gallup poll, to give a bird's eye view of the lower tribunals' reaction. ${ }^{3 B}$ But a more useful approach would seem to be a consideration of the weight given by these tribunals to various factors when deciding whether or not each particular situation falls within the rule. In the Clifford opinion stress was laid on the length of the trust term, the identity of the trustee, the identity of the beneficiaries, and the control retained by the grantor. Whereas the Court remarked that all considerations and circumstances of the kind it had mentioned were relevant to the question of ownership and hence left the way open for taking cognizance of different or additional attributes which may be present in other situations, ${ }^{37}$ the factors adverted to in the Clifford decision were, as might be expected, given primary consideration in the post-Clifford cases. Indeed, they are among the more usual indicia of ownership present in trusts of the type under

bility of $\$ 22(a)$, first raised by the Commissioner before that tribunal. The Supreme Court held that it should have done so, but, for the same reason as in the Hormel ease, gave direction to the court below to remand the case to the Board for rehearing. The trust here was revocable by the grantor with the consent of his wife at any time befure its termination. This would seem to place control over the trust "completely in the hands of the taspayer and his wife," the test adverted to in the Hormol case. In wes of this circumstance it is difficult to conceive that an: addituonal endence culd result in a decision in the taxpayer's favor.

36. See appendix, infra pp. 251-52, where the cases are so grouped.

37. In George H. Deuble, 42 B. T. A. 277, 287 (1940), the Board said: "Certain indicia of control by the grantor appeared in the Clifford case which do not appear so clearly in the trust presently before us. . . . The decision reached by the Supreme Court in Helvering $v$. Clifford was not based solely on any one of the factors present in the trust before it. Rather, it was based on the aggregate of all factors of control." 
discussion. Hence it seems appropriate to consider first the treatment accorded to these factors by the Board and the courts, preserving a chronological order where necessary in order to trace the development of an attitude.

\section{LENGTH OF TERM}

In Commissioner $v$. Branch $^{38}$ the First Circuit, singling out the statcment in the Clifford opinion that certiorari was granted "because of the importance to the revenue of such short term trusts in the reduction of surtaxes," ${ }^{30}$ refused to apply the rule to a grantor who, while reserving broad powers of management, had created a trust to run for the life of the beneficiary, his wife. And the Second Circuit followed the Branch case without opinion where a family trust with a similar term was involved. ${ }^{40}$

But it may be asserted with some confidence that these earlier court decisions ${ }^{41}$ have already been modified. In White v. Higgins ${ }^{42}$ the First Circuit, while observing that the life insurance trusts there involved were not short-term trusts, recognized the force of the Clifford observation that "no one fact is normally decisive" and concluded that the economic realities, namely, the extent of the settlor's continued dominion over corpus, required that the income should be taxed to her. A few months later, the same court remanded to the Board for consideration of the applicability of Section 22(a) a case involving a fifteen-year trust, ${ }^{43}$ and in Commissioner v. Berolaheimer ${ }^{44}$ the Second Circuit did not hesitate to extend the Clifford rule to a ten-year trust.

38. 114 F. (2d) 985 (C. C. A. 1st, 1940).

39. 309 U. S. 331,334 (1940).

40. Helvering v. Palmer, 115 F. (2d) 368 (C. C. A. 2d, 1940). In Jones v. Norris, 122 F. (2d) 6 (1941) (20-year trust), the Tenth Circuit also relied in part on the Branch case.

41. See also Kent v. Rothensies, 35 F. Supp. 291 (E. D. Pa. 1940), rev'd on ollicr grounds, 120 F. (2d) 476 (C. C. A. 3d, 1941); cf. Commissioner v. Prouty, 115 F. (2d) 331 (C. C. A. 1st, 1940).

42. 116 F. (2d) 312 (C. C. A. 1st, 1940).

43. Commissioner v. O'Keeffe, 118 F. (2d) 639 (C. C. A. 1st, 1941).

44. 116 F. (2d) 628 (1940). The Tenth Circuit in Cox v. Commissioner, 110 li. (2d) 934 (1940), cert. denied, 311 U. S. 667 (1940), held taxable to the grantor under $\$ 22$ (a) the income of a trust for the grantor's life, but it must be noted that the court felt he had, in effect, a power of revocation. Moreover, the case is complicated by the fact that it involved cross-trusts and is hence atypical, since such reciprocal transfers of property, no matter for how long a period, will usually effect no change in the dominion and control exercised by the respective transferors who emerge as trustce-managers of the property transferred by their opposite numbers. Two Board cases holding the income of long-term trusts taxable to the settlor involve similar situations. Purdon Smith Whiteley, 42 B. T. A. 316 (1940); R. Douglas Stuart, 42 B. T. A. 1421 (1940). 
The Board also seems to have vacillated. It has decided against the taxpayer in some cases involving lifetime trusts, ${ }^{15}$ presumably because the elements of retained control probably exceeded, in the aggregate, those reserved by Clifford. Yet, in a number of cases $^{40}$ it has adduced the lifetime or long-term feature of the trust as one of the reasons for refusing to hold the grantor taxable on the income; none of these opinions, however, contained any statement as unequirocal as that made in the Branch case. No clear line as to the permissible length of term has been drawn. In Frank E. Wolcott t7 the Board mentioned as an element in distinguishing the Clifford case the "long term" of four trusts which varied between 9 and 22 years, whereas in two other cases it has held the income of ten-year trusts taxable to the settlor. ${ }^{48}$ It should be pointed out that in one of the latter, Siowiden Fahnestock, the Board relied on the Second Circuit's decision in favor of the Government with respect to the ten-year trust of the Berolahcimer case, ${ }^{49}$ and that the $W$ olcott opinion, holding to the contrary, was promulgated prior to this decision.

If a long-term trust will not necessarily escape the Clifford rule, does it follow that one created for only a short span of years will inevitably be within its ambit? The Board in several cases involving trusts of quite brief duration ${ }^{50}$ has answered the question in the negative, usually

45. Mírton Stein, 41 B. T. A. 994 (1940); Reginald B. Parsons, 44 B. T. A. 1142 (1941). Another board case involving long-term trusts must be deemed atypieal in that there the income was held taxable to the husband-trustee because the terms of the trust instrument gave him such control over the corpus that the wife-grantor vas deemed in substance to have made a gift to him, individually, of the corpus when she created the "trust." H. S. Richardson, 42 B. T. A. $\$ 30$ (1940), aff'd sub uom. Richardson v. Commissioner, $121 \mathrm{~F}$. (2d) 1 (C. C. A. 2d, 1941). It may also be noted that in a case involving a basis question the Board assumed that the grantor of trusts running for several lives, which, however, were revocable by trustees having non-adverse interests, might have been taxed during his lifetime on the trust income under the Clifford rule; the beneficiaries were members of his immediate family but the opinion does not indieate that the grantor reserved any control over the corpus. Minnie M. Fay Trust "A", 42 B. T. A. 765,768 (1940).

46. Lolita S. Armour, 41 B. T. A. 777 (1940), on appcal C. C. A. 7th; Antoinette K. Erown, 42 B. T. A. 693 (1940), rev'd sub non. Commissioner v. Brown, 4 C. C. H. 1941 Fed. Tax Serv. I 9667 (C. C. A. 3d, 1941); Frank E. Wolcott, 42 B. T. A. 1151 (1940); Jessie W. Donahue, 44 B. T. A. 329 (1941).

47. Frank E. Wolcott, 42 B. T. A. 1151 (1940).

48. Snowden Fahnestock, 43 B. T. A. 569 (1941); Robert H. Cory, 3 C. C. H. 1941 Fed. Tax Serv. $\llbracket 7272-B$ (B. T. A. mem.).

49. $116 \mathrm{~F}$. (2d) $62 \mathrm{~S}(1940)$.

50. Dunlevy T. Mrilbank, 41 B. T. A. 1014 (1940) (3 and 5 ycars); Edma B. Elizs, 41 B. T. A. 1109 (1940) (7 years), rev'd sub nom. Helvering v. Elias, 122 F. (2d) 171 (C. C. A. 2d, 1941) ; John P. Wilson, 42 B. T. A. 1260 (1940) (2 years), on afpeal C. C. A. $7 t h$; Elizabeth K. Lamont, 43 B. T. A. 61 (1940) (1 year), os opfcal C. C. A. $2 d$. 
because the grantor was deemed to have retained little or no control. The Second Circuit, in various opinions interpreting the Clifford case, has arrived at what may seem an illogical result. In Helvering $v$. Achelis ${ }^{51}$ it insisted that the Clifford opinion did not suggest that a trust settlor could not so completely sever himself from the income as to make it no longer his, even though the trust term be short. Y'et in Commissioner v. Buck ${ }^{52}$ this same court ${ }^{53}$ said that the control factor is sufficiently present merely because a trust is of short duration; this is true, the court explained, even if there are no express reservations of control because the grantor will soon reacquire complete dominion. The beneficiaries of the Achelis trust were not members of the family group, and in a similar short-term trust situation decided soon thereafter, ${ }^{55}$ this lack of "family flavor" was seized upon to distinguish the Clifford case. But such a distinction seems rather unsatisfactory because, if early reacquisition of dominion over corpus imports control, stuch control cannot be deemed affected by the identity of the beneficiaries.

In any event it seems that the length of the trust term is, at most, a cumulative factor. ${ }^{50}$ Indeed, in view of Mr. Justice Douglas' dictum in Helvering v. Fuller ${ }^{57}$ it may be argued that in some cases the longer the term, the more reason for taxing the grantor. There, it will be recalled, a ten-year alimony trust had been set up with the corpus to go to the divorced wife at the end of the term. The observation was made that the income might be taxable to the settlor under the Clifford rule because he had retained considerable control over the trusteed securities. ${ }^{58}$ If a grantor to whom the corpus will never revert is taxable

51. 112 F. (2d) 929 (C. C. A. 2d, 1940) (6 years).

52. 120 F. (2d) 775 (C. C. A. 2d, 1941). See also Commissioner v. Barbour, 122 F. (2d) 165 (C. C. A. 2d, 1941). In Commissioner v. Woolley, 122 F. (2d) 167 (C. C. A. 2d, 1941), settlor reserved legal, if indirect, control over the corpus of a short-term trust; hence the summary of that holding as given in Helvering v. Elias, $122 \mathrm{~F}$. (2d) 171,172 (C. C. A. 2d, 1941), seems inaccurate.

53. This volte face seems all the more amazing since two judges, Learned Hand and Chase, sat in both cases.

54. The dictum of the Buck case may become a well-defined rule, for in Helvering v. Elias, 122 F. (2d) 171 (C. C. A. 2d, 1941), the court defined "short term" to mean "six or seven years"; if the term is longer "settlor's legal reservation of control becomes vital." Thus the court harmonized its decision in taxpayer's favor with reference to the ten-year trust involved in Commissioner v. Jonas, $122 l^{\circ}$. (2d) 169 (1941), promulgated one day prior to the Elias case.

55. Commissioner v. Chamberlain, 121 F. (2d) 765 (C. C. A. 2d, 1941). Here settlor, as one of two co-trustees of a four-year educational purpose trust, reserved substantial control over corpus; the Achelis case was followed "though not without some doubt."

56. See Elizabeth K. Lamont, 43 B. T. A. 61, 67 (1940). The absence of a specific term is immaterial. David M. Heyman, 44 B. T. A. 1009 (1941).

57. 310 U. S. 69, 76 (1940).

58. One circuit court, in a case where grantor "exercised autocratic powers over the trust estate", has held that if he retains "neither the power to revoke, rev'cst or revert 
on its income because he retains control over the corpus for ten years, would the same not follow a fortiori if he projected his control even farther into the future?

\section{IDENTITY OF THE TRUSTEE}

Just as the short-term element is not a sine qua non for applying the rule of the Clifford case, so the fact that the grantor did not, as in that case, appoint himself the sole trustee, has not been - and, it is submitted, should not be - deemed decisive. True, in one opinion ${ }^{59}$ handed down shortly after the Clifford decision, the Board laid great emphasis on the fact that the grantor did not declare herself trustee but appointed her husband to act as such with all powers of management. Such an attitude would seem to fly in the face of MIr. Justice Douglas' admunition not "to let mere formalism obscure the normal consequences of family solidarity," ${ }^{60}$ unless - and this consideration was nowhere urged by the Board - the justification for treating the husband "as a complete stranger" 1 is rested on the somewhat doubtful assumption that the male must always be presumed the dominant marital partner. ${ }^{\text {c2 }}$ While it may be noted that with one exception ${ }^{13}$ all decisions have gone against the taxpayer-grantor where he has made himself sole trustee,

either the corpus or the income . . . there can be no substantial incidents or attributes of ownership, sufficient to vest in the grantor any of the economic benefits of the trust, essential to taxation under . . . Section 22(a)." Jones v. Norris, $122 \mathrm{~F}$. (2.1) 6-11 (C. C. A. 10th, 1941). This conclusion is clearly inconsistent with the suggestion thrown out by Mr. Justice Douglas in the Fuller case.

The Board has held that reversion of corpus to the grantor standing by itself is no reason for the application of the Clifford rule. Reginald B. Parsons, 44 B. T. A. 1142 (1941); but that the absence of such reversion is one of the factors which may serve to distinguish the Clifford case [see John N. Fulham, 44 B.T. A. 1183 (1941)] or, of itself, will do so. Rose L. Ray, 3 C. C. H. 1941 Fed. Tax Serv. T 7474-A (B. T. A. mem.).

59. Edna B. Elias, 41 B. T. A. 1109 (1940) (6 dissented), rca'd sub nom. Helvering v. Elias, 122 F. (2d) 171 (C. C. A. 2d, 1941). See also Dunlery T. Mrilbank, 41 B. T. A. 1014 (1940), where the Board laid some stress on the identity of the trustee-in that case the grantor's wife-but where additional factors were present which made the case stronger for the taxpayer.

60. 309 U. S. 331,336 (1940).

61. Ibid.

62. Judge Learned Hand in Helvering v. Elias, 122 F. (2d) 171 (C. C. A. 2d, 1941), assumes a certain amenability on the part of the husband-trustee.

63. Lolita S. Armour, 41 B. T. A. 777 (1940), on appcal C. C. A. ilh. Cf. Edward H. Heller, 41 B. T. A. 1020 (1940), where a father was held to have acted as guardian in the management of his children's property rather than as trustee.

64. Penn v. Commissioner, 109 F. (2d) 954 (C. C. A. Sth, 1910); First Nat. Bank v. Commissioner, 110 F. (2d) 448 (C. C. A. 7th, 1940); Thomson v. Helvering, $114 \mathrm{~F}$. (2d) 607 (C. C. A. Sth, 1940); Commissioner v. Berolzheimer, 116 F. (2d) 623 (C. C. A. 2d, 1940); Reuter v. Commissioner, 118 F. (2d) 098 (C. C. A. 5th, 1941); Reuter v. 
no similar convenient rule of thumb can be applied where he has cotrustees associated with him $^{65}$ or has appointed as trustee a close relative, ${ }^{60}$ a friend or employee, ${ }^{67}$ or a bank. ${ }^{68}$ Even where a financial institution has been named, it seems that if the grantor has retained the power to substitute himself as trustee, he should be regarded for purposes of decision as the trustee, whether he has seen fit to exercise the power or not; and, generally, the cases so hold. ${ }^{\text {in }}$ If he is one of

United States, 34 F. Supp. 1014 (Ct. Cl. 1940), ccrt. denied, 312 U. S. 695 (1941); Snowden Fahnestock, 43 B. T. A. 569 (1941); William J. MeCormack, 43 I. I. A. 924 (1941) ; David M. Heyman, 44 B. T. A. 1009 (1941).

65. See Hormel v. Helvering, 312 U. S. 552 (1941) ; Cox v. Commissioner, $110 \mathrm{~F}$. (2d) 934 (C. C. A. 10th, 1940), cert. denied, 311 U. S. 667 (1940); Commissioner v. Branch, 114 F. (2d) 985 (C. C. A. 1st, 1940); Helvering v. Palmer, 115 F. (2d) 368 (C. C. A. 2d, 1940), aff'g. Carleton H. Palmer, 40 B. T. A. 1002 (1939); White v. Higgins, 116 F. (2d) 312 (C. C. A. 1st, 1940); Helvering v. Dunning, 118 F. (2d) 341 (C. C. A. 4th, 1941) ; Commissioner v. O'Keeffe, 118 F. (2d) 639 (C. C. A. 1st, 1941); Kent v. Rothensies, 35 F. Supp. 291 (E. D. Pa. 1940), rev'd, 120 F. (2d) 476 (C. C. A. 3d, 1941) ; Commissioner v. Chamberlain, 121 F. (2d) 765 (C. C. A. 2d, 1941); Stanley v. Smith, 4 P. H. 1941 Fed. Tax Serv. $\pi 62,823$ (D. Conn. 1941); Morton Stein, 41 B. T. A. 994 (1940); John N. Fulham, 44 B. T. A. 1183 (1941); Estate of Willian Childs, 44 B. T. A. 1191 (1941) ; Frederick Ayer, 3 C. C. H. 1941 Fed. Tax Serv. \7 7083 (B. T. A.). See also Purdon Smith Whiteley, 42 B. T. A. 316 (1940), where the benteficiary, whom the Board held in effect to be the grantor, was a co-trustee.

66. Dunlevy T. Milbank, 41 B. T. A. 1014 (1940) (wife); Edna B. Elias, 41 B. 'l'. A. 1109 (1940) (husband), rez'd sub nom. Helvering v. Elias, 122 F. (2d) 171 (C. C. A. 2d, 1941) ; Antoinette K. Brown, 42 B. T. A. 693 (1940), ret'd sul nom. Commissioner v. Brown, 4 C. C. H. 1941 Fed. Tax Serv. $₫ 9667$ (C. C. A. 3d, 1941) (brother). See also Altmaier v. Commissioner, 116 F. (2d) 162 (C. C. A. 6th, 1940), ccrt. denticl, 312 U. S. 706 (1941) (wife); H. S. Richardson, 42 B. T. A. 830 (1940) (husband), aff'd sub nom. Richardson v. Commissioner, 121 F. (2d) 1 (C. C. A. 2d, 1941); Commissioner v. Woolley, 122 F. (2d) 167 (C. C. A. 2d, 1941) (wife).

67. Jones v. Norris, 122 F. (2d) 6 (C. C. A. 10th, 1941) (confidential employec); Elizabeth K. Lamont, 43 B. T. A. 61 (1940) (intimate friend), on appeal C. C. A. 2d; Archibald G. Bush, 43 B. T. A. 535 (1941) (friendly business associate); Willian L.. McKnight, 3 C. C. H. 1941 Fed. Tax Serv. $\llbracket 7271-B$ (B. T. A. mem.) (ibid.).

68. Commissioner v. Buck, 120 F. (2d) 775 (C. C. A. 2d, 1941); George H. Deuble, 42 B. T. A. 277 (1940), on appeal C. C. A. 6th; Herbert W. Hoover, 42 B. T. A. 289 (1940), on appeal C. C. A. 6th; Frank G. Hoover, 42 B. T. A. 786 (1940); Frank 1.. Wolcott, 42 B. T. A. 1151 (1940) ; Arthur M. Betts, 3 C. C. H. 1941 Fed. Tax Serv. I 7116-D (B. T. A. mem.) ; William J. Garland, 43 B. T. A. 731 (on rehearing, 1941); Jessie W. Donahue, 44 B. T. A. 329 (1941); Reginald B. Parsons, 44 B. 'T. A. 1142 (1941). See also Frick v. Driscoll, 4 P. H. 1941 Fed. Tax Serv. $\llbracket 62,383$ (W. D. Pat 1941) ; Helvering v. Richter, 312 U. S. 561 (1941); Commissioner v. Ward, 119 F. (21) 207 (C. C. A. 3d, 1941).

69. See George H. Deuble, Herbert IV. Hoover, Frank G. Hoover (but grantor likewise held taxable in a year when he did not have the power of substitution), cited sttpra note 68. But in Jones v. Norris, 122 F. (2d) 6 (C. C. A. 10th, 1941), and Antoinette K. Brown, 42 B. T. A. 693 (1940), rev'd sub nom. Commissioner v. Brown, 4 C. C. H. 1941 Fed. Tax Serv. $\llbracket 9667$ (C. C. A. 3d, 1941), the Board attributes no weight to the grantor's power to change the trustee. A similar omission in Eilua $B$. 
several trustees, clearly he should be regarded as though he were the sole trustee if his powers materially exceed those of his fellows, ${ }^{\text {in }}$ or if his powers enable him to control all of their activities. ${ }^{\text {in }}$ In the Hormel case $^{\mathrm{i2}}$ the Supreme Court, we have seen, ${ }^{\mathrm{i3}}$ intimated that in family trust cases it would treat one spouse as the other's alter ego. ${ }^{\text {it }}$ Ience the appointment of a wife or husband as trustec will presumally lix treated as what it almost invariably is, an empty gesture.

Elias, 41 B. T. A. 1109 (1940), reid sub nom. Helvering v. Elias, 122 F. (2d) 171 (C. C. A. 2d, 1941), seems particularly subject to criticism for there the Buard stressed as a reason for decision that the grantor did not declare herself trustee; in reversing, the court also failed to mention this important reserved power. See also Hurmel v. Helvering, 312 U. S. 552 (1941), where the grantor-trustee and his wife could jointly remove the co-trustee at any time and choose a successor; White v. Higgins, 116 IF. (241) 312 (C. C. A. 1st, 1940), where grantor-trustee had power to remove any co-trustce without being obliged to name a successor; and Commissioner v. Buck, 120 F. (2.l) 775 (C. C. A. 2d, 1941), where grantor could remove the trustee at his pleasure.

70. Purdon Smith Whiteley, 42 B. T. A. 316 (1940). Broad powers of mamagement exercisable without the consent of co-trustees were held insufficient, however, to render grantor taxable in Commissioner v. Branch, Helvering v. Palmer, and Kent v. Ruthensies, cited supra note 65 .

71. See, c.g., Morton Stein, 41 B. T. A. 994 (1940), where the Board stressed the grantor-trustee's power to appoint any number of additional co-trustees. Cf. Commissioner v. Branch, 114 F. (2d) 985 (C. C. A. Ist, 1940), where a similar power was apparently deemed unimportant.

72. 312 U. S. 552 (1941).

73. See p. 220 supra.

74. Identity of interest with the grantor was found to exist where the spouse was one of two co-trustees possessing power of revocation. R. Douglas Stuart, 42 E. T. A. 1427 (1940), on appial C. C. A. 7th. But quacre whether sueh identity will be found to exist where the husband-grantor has power to revole at any time with the consent of a wife-beneficiary who, traditionally, might be thought to have a "substantial aulverse interest." See Helvering v. Kichter, 312 U. S. 561 (1941), remanded fur snecific consideration by the Board of the applicability of $\$ 22$ (a) contemporaneously with the IIarmel case. Compare David M. Heyman, 44 B. T. A. 1009 (1941), with Estate of William Childs, 44 B. T. A. 1191 (1941). For instances where family solidarity between husband and wife has been disregarded, see Commissioner v. Branch, 114 F. (21) 935 (C. C. A. 1st, 1940) ; Commissioner v. Prouty, 115 F. (2d) 331 (C. C. A. Ist, 1940) (gift tax); Commissioner v. Park, 113 F. (2d) 352 (C. C. A. 3d, 1940) (deductibility of interest on note gratuitously given to wife); Edna B. Elias, 41 B. T. A. 1109 (1940), rec'd sub nom. Helvering v. Elias, 122 F. (2d) 171 (C. C. A. 2d, 1941); Helvering v. Palmer, 115 F. (2d) 368 (C. C. A. 2d, 1940) (trusts could be amended so as to revest principal in grantor by written agreement of the trustees, who were the grantur and his wife, and the adult beneficiaries; but all beneficiaries uther than the wife vere minors when the trust was created. See Carleton H. Palmer, t0 B. T. A. 1001 (1939)). In Estate of Isaac Fish, 42 B. T. A. 260 (1940), a wife-beneficiary was held to have a substantial adverse interest. The Board later pointed out that this case was decided fuur months after the Clifford case and that the Commissioner acquiesced therein. Estate of William Childs, 44 B. T. A. 1191 (1941). But the Board seems to have overloothed the Hormel case decided after the Commissioner's acquiescence. See also Estate of Fredericl: S. Fish, 45 B. T. A. 120 (1941). 
It is submitted that a similarly realistic approach should be used where a third party is appointed trustee. The Second Circuit has done so in Commissioner v. Barbour" where it observed that it was "reasonable to suppose" that the grantor, who had not reserved any express control, "felt confident" that his lawyers, whom he had made trustees, "would observe his reasonable wishes as to investment and management." 76 The Board, also, in the McKnight and Bush cases ${ }^{77}$ where the officers of a company appointed as trustee its Assistant Treasurer, thought him "no more than a friendly middleman in the family negotiations." A similar conclusion should perhaps have been reached in the earlier Lamont case ${ }^{78}$ where the trustee, settlor's "intimate friend and attorney," who might, as the Board itself noted, be thought stbject to her influence because of fees to be earned in connection with her other affairs, was treated as wholly independent. The Board justified its conclusion by professing inability to draw a line based on considerations of the extent to which a trustee outside of the family group, such as an ordinary commercial trustee, might be under the influence of its client-settlor. But the Clifford rule calls for "an analysis of the terms of the trust and all the circumstances attendant on its creation and operation."79 Thus, if a bank functioning as trustee is found to have lent to the grantor without collateral a substantial portion of the assets of the trust, ${ }^{80}$ such compliance with his wishes ought, it is submitted, to be considered in determining its freedom from influence. ${ }^{81}$

\section{IDENTITy OF THE BenEFiciaries}

The Clifford opinion seemed to place particular emphasis on the fact that the beneficiaries were members of the grantor's "family group" and that the trust accomplished a reallocation of income within "an in-

75. 122 F. (2d) 165 (C. C. A. 2d, 1941).

76. But cf. Jones v. Norris, 122 F. (2d) 6 (C. C. A. 10th, 1941), where the court disregarded the fact that the trustee was a confidential employee and the grantor had "exercised autocratic powers over the trust estate."

77. William L. McKnight, 3 C. C. H. 1941 Fed. Tax Serv. $\{7271-B$ (B. T. A. mem.); Archibald G. Bush, 43 B. T. A. 535 (1941).

78. Elizabeth K. Lamont, 43 B. T. A. 61 (1940), on appeal C. C. A. 2 dl.

79. Italics supplied. 309 U. S. 331, 335 (1940).

80. As in Frank E. Wolcott, 42 B. T. A. 1151 (1940).

81. In the Buck case, where a bank was trustee, the Second Circuit flatly asserted that the Supreme Court's decision in Helvering v. Richter, 312 U. S. 561 (1040), had removed as a "significant difference" the fact that the grantor was not the trustec. It is difficult to understand how such a sweeping inference can be drawn from that opinion, which dealt with a procedural question, especially since the trust company which had been made trustee could be ousted at any time the grantor and his wife chose to revole the trust. It is submitted that the Supreme Court has not yet spoken with regard to an independent trustee who cannot be ousted either by substitution or by revocation of the trust. 
timate family group." "22 This concept might reasonably be deemed to include no more than the grantor's spouse and children, plus, conceivably, dependent relatives living under his roof. ${ }^{83}$ But, strangely enough, in cases holding the grantor taxable, inclusion among the ranks of the beneficiaries of a sister for whose support he felt responsible, ${ }^{8 t}$ of his parents, ${ }^{85}$ of brothers, sisters, sisters-in-law and cousins. ${ }^{85}$ has been passed over $s u b$ silentio. ${ }^{87}$ Though it is true that in some cases where

82. The Board seems to suggest as a criterion whether the relative would be an heir, should grantor die intestate (see Herbert W. Hoover, 42 B. T. A. 289, 297 (1940), an appeal C.C. A. 6 th) ; or whether grantor is under any legal duty to support the relstive (see Elizabeth K. Lamont, 43 B. T. A. 61, 66 (1940), on affeal C. C. A. 2d). Whereas the latter test would be significant in considering the rule of Douglas v. Willcuts, 296 U. S. 1 (1935), and other cases touching this subject, it seems quite beside the point here, since the Clifford trust "was not designed to relieve respondent from liability for family or household expenses." 309 U. S. 331, 333 (1940). That the beneficiaries of a trust are members of the grantor's family is, of itself, not enough to malie the Clifford rule applicable. George H. Deuble, 42 B. T. A. 277 (1940), on apscal C. C. A. 6th (see the "income" trusts). Two circuit courts seem to regard a family relationship between settlor and cestuis as an indisnensable element to invuke applicability of the rule: Kraft v. Commissioner, 111 F. (2d) 370 (C. C. A. 3d, 1940), cert. denicd, 311 U. S. 671 (1940); Commissioner v. Chamberlain, 121 F. (2d) 765 (C. C. A. 2d, 1941). Certainly, the complete disregard of this factor, as in John P. Wilson, 42 B. T. A. 1260 (1940), on appeal C. C. A. 7 th, would seem just cause for adverse criticism. The Sisth Circuit, in Altmaier v. Commissioner, 116 F. (2d) 162 (C. C. A. (th, 1940), cort. denicd, 312 U. S. 706 (1941), and in Commissioner v. Central Nat. Bank, 119 F. (2d) 470 (C. C. A. 6 th, 1941), refers to Helvering v. Horst, 311 U. S. 112 (1940), as giving additional stress to the "family solidarity" concept. This interpretation seems doubtful since there the assignor of income was taxed on the theory that by his assigument he procured a satisfaction such "as may result from the payncnt of a campaign ur community chest contribution, or a gift to his favorite son." The Herst case is discussed infra p. 230.

83. Cases dealing with the personal exemption available to the head of a family under $\$ 25(\mathrm{~b})(1)$ of the Revenue Acts of 1934 and $1936 \mathrm{may}$ furnish persuasive analogies. See, e.g., Ellis v. Commissioner, 110 F. (2d) 954 (C. C. A. 5th, 1940); V'ade v. Helvering, 117 F. (2d) 21 (App. D. C. 1940); Claude S. Rucker, 42 B. T. A. 32 (1940); Richard H. Baumbach, 42 B. T. A. \& (1940); Charlotte Hoskins, 42 B. T. A. 117 (1940) ; Estate of Grace Adams Howard, 42 B. T. A. 449 (1940); L. B. Hirsch, 42 E. T. A. 566 (1940); Percival Parrish, 44 B. T. A. 144 (1941); J. Brooks B. Parker, 44 B. T. A. 369 (1941).

84. Archibald G. Bush, 43 B. T. A. 535 (1941).

85. Reuter v. United States, 34 F. Supp. 1014 (Ct. Cl. 1940), ccrt. dcsicd, 312 (I. S. 095 (1941), Reuter r. Commissioner, 118 F. (2A) 698 IC. C. A. 5 th, 1941).

85. First Nat. Bank v. Commissioner. 110 F. (2d) 448 (C. C. A. 7 th, 1010), Cos $\because$ Commissioner, 110 F. (2d) 934 (C. C. A. 10th, 1940), cort. desico, s11 C. S. 697 (1940) ; both these cases, however, involve reciprocal trusts and may hence be considered somewhat abnormal.

87. Only the Second Circuit has discussed the point when holding "in the family" a dependent nephew, though he was not a member of settlor's household. Commissioner v. Woolley, 122 F. (2d) 167 (C. C. A. 2d, 1941); and as within the "intimate family" group" a mother-in-law living in another town, the taxpayer having failcd to meet the burden of demonstrating the error of such a shocking presumption. Commissioner $v$. Barbour, 122 F. (2d) 165 (C. C. A. 2d, 1941). 
decision went in his favor, the fact that the beneficiaries were not members of his immediate family circle has been stressed, it has gone unmentioned in about as many. ${ }^{88}$ It seems that the length of the trust term and the quantum of control reserved by the grantor weigh more heavily with the Board and the lower courts (except the Second Circuit $^{89}$ ) than degrees of relationship.

The intuition of these tribunals would seem to have been sound for in Harrison z'. Schaffner ${ }^{00}$ the Supreme Court referred to the Clifford case as determining taxability to the donor of income which he "gives away through the medium of a short-term trust created for the benefit of the donee", i.e., apparently, any donee. Moreover, in Hclviring i. Fuller, ${ }^{91}$ a case involving a trust created to take care of a wife's needs after the family group had been shattered by divorce, the Supreme Court indicated that the all-important - and perhaps, it may be ventured, the solely decisive - factor when considering the applicability of the Clifford rule was the quantum of control retained by the grantor. ${ }^{\text {pg }}$

\section{Control}

A short-term trust, the appointment of one's self or of a compliant person as trustee, and the naming of close relatives as beneficiaries are not, as we have seen, rigid limitations beyond which the rule of the Clifford case is inapplicable. Each of these elements is indicative of the extent to which the grantor has, realistically speaking, remained "the owner of the corpus," ${ }^{3}$ but all of them are merely examples of means which may be chosen to keep dominion over trusteed property. Hence it is important to determine whether the cases have taken a broader approach and have analyzed the situations presented in order to ascertain not only from the trust instrument, but also from "all circumstances

88. Remoteness stressed: Commissioner v. Chamberlain, 121 F. (2d) 765 (C. C. A 2d, 1941) (educational corporation); Lolita S. Armour, 41 B. T. A. 777 (1940) (daughter who had established own home and family ties); Elizabeth K. Lamont, $43 \mathrm{~B}$. T. A. 61 (1940), on appcal C. C. A. 2d, (first cousins, not members of settlor's houseliold); Dunlevy Milbank, 41 B. T. A. 1014 (1940) (sister-in-law and uncle, not members of immediate family çircle); Jessie W. Donahue, 44 B. T. A. 329 (1941) (deceased lius: band's brothers and sisters).

Remoteness not mentioncd: Helvering v. Achelis, 112 F. (2d) 929 (C. C. A. $2 \mathrm{~d}$, 1940) (educational corporation); Antoinette K. Brown, 42 B. T. A. 693 (1940), rwil sul nom. Commissioner v. Brown, 4 C. C. H. 1941 Fed. Tax Serv. $\{9667$ (C. C. A. 3d, 1941) (servant and friend); Arthur M. Betts, 3 C. C. H. 1941 Fed. Tax Serv. ff 7116-D (B. T. A. mem.) (parent).

89. Commissioner v. Chamberlain, 121 F. (2d) 765 (C. C. A. 2d, 1941), discusscd supra note 55.

90. 312 U. S. 579 (1941).

91. 310 U. S. 69 (1940).

92. Contra: Reginald B. Parsons, 44 B. T. A. 1142 (1941).

93. Helvering v. Clifford, 309 U. S. 331, 334 (1940). 
attendant on [the] creation and operation"94 of the trust, what economically significant controls the grantor has retained.

The Clifford opinion singles out control over investment, ${ }^{05}$ and by and large the cases give great importance to this factor. ${ }^{30}$ let a few opinions have asserted, one with rather cavalier treatment of its reituration as "the dictum in Hclicring a'. Fullor," that retention of broad powers of management either qua trustee ${ }^{98}$ or quu grantor ${ }^{99}$ is insulficient reason for taxing the income to the grantor.

The lending of trust corpus by a grantor either to himself or to enterprises under his control or management has been recognized as a significant indicium of ownership by the Seventh Circuit ${ }^{100}$ and should be so considered even where the trustee is a third party. The Board might be criticized for only giving weight to this factor ${ }^{101}$ where pro-

94. Id. at 335. Such consideration of extrinsic evidence is to be found increasingly in the cases. Cf. Buhl v. Kavanaugh, 118 F. (2d) 315, 321 (C. C. A. Gth, 1941), in which the court said that such evidence will be considered only if the written instrument is uncertain or indefinite in its contents.

95. 309 U. S. $331,335$.

96. See, c.g., Reuter v. United States, 34 F. Supp. 1014 (Ct. Cl. 1940), corl. derticd, 312 U. S. 695 (1941) ; First Nat. Bank v. Commissioner, 110 F. (2d) 448 (C. C. A. 7th, 1940) ; Commissioner v. Buck, 120 F. (2d) 775 (C. C. A. 2d, 1041); Gcorge H. Deuble, 42 B. T. A. 277 (1940), on appcal C. C. A. Oth; Snowden Fahnestock, 43 B. T. A. 569 (1941) (grantor-trustee's argument that his power of reinvestment was limited by state law disregarded in view of actual investments made); Robert H. Cory, 3 C. C. H. 1941 Fed. Tax Serv. I7272-B (B. T. A. mem.) (distinguishing power to direct investments from right merely to disapprove those suggested by the trustee). (\%. Frank E. Wolcott, 42 B. T. A. 1151 (1940).

97. Commissioner v. Branch, 114 F. (2d) 985 (C. C. A. 1st, 1940), referring tu 310 U. S. $69,76(1940)$.

98. Commissioner v. Branch, 114 F. (2d) $9 S 5$ (C. C. A. 1st, 1940); Kent v. Rathensies, 35 F. Supp. 291 (E. D. Pa. 1940), recid on other grounds, 120 F. (2d) 476 (C. C. A. 3d, 1941); Carleton H. Palmer, 40 B. T. A. 1002 (1939), aff'd on authorily of Branch case sul) nom. Helvering v. Palmer, 115 F. (2d) 368 (C. C. A. 2d, 1940); John N. Fulham, 44 B. T. A. 1183 (1941) ; Frederick Ayer, 3 C. C. H. 1941 Fed. Tax Serv. $\pi 7683$ (B. T. A.). Reservation of a power merely as trustee may have important tax consequences. Cf. Terhune v. Welch, 39 F. Supp. 430 (D. Mfass. 1941) (estate tax).

99. Jones v. Norris, 122 F. (2d) 6 (C. C. A. 10th, 1941); Arthur M. Betts, 3 C. C. H. 1941 Fed. Tax Serv. I7116-D (B. T. A. mem.) ; Jessie WV. Donahue, it B. T. A. 329 (1941).

100. First Nat. Bank v. Commissioner, 110 F. (2d) 448 (C. C. A. 7th, 1940). liut see Kent v. Rothensies, 35 F. Supp. 291 (E. D. Pa. 1940), reid on olfer grounds, 120 F. (2d) 476 (C. C. A. 3d, 1941).

101. H. S. Richardson, 42 B. T. A. 830 (1940), aff'd sub nom. Richardson v. Commissioner, 121 F. (2d) 1 (C. C. A. 2d, 1941); David A. Heyman, 44 B. T. A. 1009 (1941); see also Estate of William J. Garland, 43 B. T. A. 731 (1941) (dceided under $\S 166)$. But see Edna B. Elias, 41 B. T. A. 1109 (1940), rev'd sub nom. Helvering $\%$ Elias, 122 F. (2d) 171 (C. C. A. 2d, 1941), where the Board fails to refer to a clause permitting a husband-trustee to borrow without security up to $80 \%$ of the corpus at a ridiculously low rate of interest; the adverb is used advisedly since the rate was $4 r_{c} c$ and the trust was created on July 1, 1929. 
vision for such loans appeared in the trust instrument for if the loans are actually made during the operation of the trust ${ }^{102}$ the Clifforl decision commands that they be noticed. Surely such loans, especially when made without security, indicate substantial retention of control particularly since, in these family trusts, it is open to question whether repayment will ever be insisted upon by the cestuis.

Again, the right to vote trusteed stock, coupled with control over investment and reinvestment, was held by the Board in Georgc $H$. Deuble ${ }^{103}$ a "requisite vital" element of control sufficient to bring the Clifford rule into play although the trust involved lacked many of the features of the Clifford trust. The Board correctly pointed out that applicability of the rule depended on no one particular factor but on the aggregate of all factors of control. Naturally, the significance of the right to vote should also be appraised realistically since it depends upon the nature of the trust corpus. If the latter consists of relatively small blocks of stock in large nationally owned corporations, such as General Motors or Standard Oil of New Jersey, the retention of the right to vote means little, but if a grantor has trusteed shares of a company in which he, singly or together with associates or relatives, has a dominant interest, that right assumes quite a different importance. ${ }^{101}$ It enables him to have, in the words of the Clifford opinion, "rather complete assurance that the trust will not effect any substantial change in his economic position." 105

102. As in Frank E. Wolcott, 42 B. T. A. 1151 (1940) (secured and unsecured), and Lady Marian Bateman, 43 B. T. A. 69 (1940) (grantor obtaincd loans by appointing part of corpus as security; Board rejected argument that she could thus secure full economic benefits from the corpus).

103. 42 B. T. A. 277 (1940), on appeal C. C. A. 6th.

104. The Second Circuit in Commissioner v. Buck, 120 F. (2d) 775, n. 2 (1941), noted that the grantor "had expressly in mind the importance of retaining voting power in a considerable block of stock in conjunction with a small group of persons who, together with him, were the dominant stockholders." The court drew attention to the fact "that control of such a block yields corporate control from which in turn may flow numerous pecuniary emoluments of substance." $C f$. Reed, J., dissenting in Helvering v. Fuller, 310 U. S. 69 (1940). But the statement made in the text shotld not be applied blindly. Thus it may be thought that the Board erred when selecting as one of the reatsons for holding a grantor not taxable on the income of a family trust his non-retention of the right to vote, quite disregarding the fact that after trusteeing certain slares lie still owned more than $50 \%$ of the stock. Frank E. Wolcott, 42 B. T. A. 1151 (1940). Furthermore, the statement of facts clearly demonstrates that he continued to cxerciso effective control over the trusteed stock which was disposed of shortly after the trust was created upon the occasion of the sale of the grantor's business which, almost certainly, had been arranged by him before the trust was set up. He continued to excreiso control over investments, many of which were in concerns which he dominated, and also borrowed quite heavily from the trust. The whole opinion seems to fly in the face of Mr. Justice Douglas' clarion call for regard for the realities.

105. 309 U. S. 331, 335-36 (1940). 
But complete certainty that the status quo will be preserved requires the complementary assurance, acquired either by way of express legal power or through a gentleman's understanding with the trustee, that the original corpus will remain undisturbed. If this additional factor is present, then, quoting the Board's language in Frank G. Hoocer, the grantor:

"does remain in a position to participate in the affairs of the business in which he is actively interested, a prerogative which proceeds from the retained equivalent of ownership of his interest in that enterprise. This is an attribute of proprietorship frequently of greater significance than the right to receive income." 10 i

The belief that there is no substantial change in a grantor's economic position despite the fact that he is only able to maintain the status quo of trusteed securities during the period when he has relinquished legal title thereto is not advanced as anything new. Such considerations may well have influenced those justices who, although dissenting in Burnet $\therefore$. $W$ ells, ${ }^{108}$ joined the majority in concurring in the alternative ground for decision in DuPont ${ }^{3}$. Commissioncr. ${ }^{103}$ In that case ${ }^{110} \mathrm{Mr}$. Irenee DuPont transferred to the Wilmington Trust Company, as trustee, certain insurance policies on his own life and 830 shares of $7 \%$ preferred stock of the Christiania Securities Company (the well-known DuPont family holding company), ${ }^{111}$ the income to be used to keep the policies in force. The trust deed neither specifically prohibited the trustee from selling the shares nor reserved to the grantor power to direct such sales, but several provisions dealing with the ultimate disposition of the corpus referred only to "the shares", thus clearly indicating an intention that the corpus be not disturbed during the trust period. Indeed, viewed realistically, it is a little absurd to imagine that the Wilmington Trust Company would have sold this Christiania preferred stock except at Mr. DuPont's direction and certainly not without his consent. The unanimous Supreme Court seens to have regarded the trust deed as having the effect of "freezing" the corpus for, in explaining its conclusion that the instrument's provisions require a determination against the taxpayer, the Court stated that "during a term of three years, the trustee . . . was to hold the principal inlact fur return to the grantor unless instructed to retain it longer." 112

106. 42 B. T. A. 786 (1940).

107. Id. at 792.

108. 289 U. S. 670 (1933).

109. Id. at 685 .

110. These details are taken from the opinions below. DuPont v. Commissioner, 63

F. (2d) 4 (C. C. A. 3d, 1933), and 20 B. T. A. 482 (1930).

111. See Mcody's Industrulss (1924) 63.

112. Italics supplied. 289 U. S. $685,688-89$ (1933). 
A good many of the family trusts considered in post-Clifford cases, which are composed of stock in corporations closely identified with the grantor, presumably have the same objective. Indeed, there is more than a presumption where the grantor in one way or another has reserved the power to prevent any sale of such securities ostensibly placed in trust. ${ }^{113}$ Even where such power is not reserved, ${ }^{114}$ a realistic approach would seem to demand the adoption of a rebuttable prestumption that the securities were to be kept intact for the duration of the trust.

Another "very vital incident of ownership" 115 not present in the Clifford trust is the retained power to change the beneficiaries of corpus and income. ${ }^{116}$ As Judge Frank has pointed out in the Buck case, where

113. First Nat. Bank v. Commissioner, 110 F. (2d) 448 (C. C. A. 7th, 1940) (family holding company stock; three relatives created trusts "to retain their family's control" of the company); Helvering v. Palmer, 115 F. (2d) 368 (C. C. A. 2d, 1940) (stock of Squibb \& Co. of which grantor was president); Commissioner v. Buck, 120 F. (2d) 775 (C. C. A. 2d, 1941) $(10,000$ shares of Wrigley stock; grantor and a few others were the dominant stockholders) ; Kent v. Rothensies, 35 F. Supp. 291 (E. D. Pa. 1940), rev'll on other grottnds, 120 F. (2d) 476 (C. C. A. 3d, 1941) (stock of Atwater Kent Maunfacturing Company of which grantor held a majority); Stanley v. Smith, 4 P. H. 1941 Fed. Tax Serv. $\llbracket 62,823$ (D. Conn. 1941) (stock of family holding company controlled by grantor); George H. Deuble, 42 B. T. A. 277 (1940), on appcal C. C. A. 6th, (stock of Climalene Company in the affairs of which grantor was actively interested; trust instrument indicates it is to be retained); Herbert W. Hoover, 42 B. T. A. 289 (1940), on appeal C. C. A. 6th, and Frank G. Hoover, 42 B. T. A. 786 (1940) (preferred and common stocks of the Hoover Company in which both grantors took an active interest); H. S. Richardson, 42 B. T. A. 830 (1940), aff'd sub nom. Richardson v. Commissioncr, 121 F. (2d) 1 (C. C. A. 2d, 1941) (stock of personal holding company); Archibald G. Bush, 43 B. T. A. 535 (1941), and William L. MeKnight, 3 C. C. H. 1941 led. 'lax Serv. $\llbracket 7271-B$ (B. T. A. mem.) (stock of Minnesota Mining \& Manufacturing Company of which grantors were directors and, respectively, vicc-president and president); William J. McCormack, 43 B. T. A. 924 (1941) (stock of personal holding company); Jessic W. Donahue, 44 B. T. A. 329 (1941) (15,000 shares of Woolworth common which trustee was instructed not to sell). See also Helvering v. Filler, 310 U. S. 69 (1940) (voting stock of Fuller Brush Company of which grantor, the president, owned two thirds); Hormel v. Helvering, 312 U. S. 552 (1941) (Hormel Company stock); Helvering v. Dunning, 118 F. (2d) 341 (C. C. A. 4th, 1941) (decided under $\$ 166$; Hynson, IVestcott \& Dunning, Inc. stock) ; Altmaier v. Commissioner, 116 F. (2d) 162 (C. C. A. 6th, 1940), cert. denicd, 312 U. S. 706 (1941) (decided under $\$ 167 ; 3,600$ common shares of "a corporation"); R. Douglas Stuart, 42 B. T. A. 1427 (1940) (decided under $\$ 166$; stock of Quaker Oats Company of which grantor was vice-president and of which his brother, who created reciprocal trusts, was president); Otto Peterson, 42 B. T. $\Lambda$. 102 (1940), , appcal dismissed, 117 F. (2d) 740 (C. C. A. 6th, 1941) (ncw stock issued to women who could not dispose thereof except under restrictions imposed by their male relatives who were the old stockholders and sole owners and managers of the corporiation).

114. Frank E. Wolcott, 42 B. T. A. 1151 (1940) (stock of Frank E. Wolcott Matutfacturing Company).

115. Morton Stein, 41 B. T. A. 994,1000 (1940).

116. Comnissioner v. Buck, $120 \mathrm{~F}$. (2d) 775 (C. C. A. 2d, 1941); Commissioner v. Brown, 4 C. C. H. 1941 Fed. Tax Serv. $\llbracket 9667$ (C. C. A. 3d, 1941); Morton Stcin, 41 
such a power is reserved by the grantor "the incomes of the memlers of his family will still be subject to his whims; should any of his family expend what he receives in a manner displeasing to Buck, or offent Buck in any way, a few words written by Buck can cut off that heneficiary's portion of the income and, later, a few more can restore it." 11 i This has the welcome ring of common sense, and one may hulpe that the warning of the Clifford case against permitting mere formalism t" obscure the normal consequences of family solidarity and against accepting legalistic concepts of ownership when invoked to cloak houseluld arrangements may result in further decisions evidencing such a refreshing attitude.

Indeed, it seems that at long last the courts are admonished to take judicial notice of matters which have always been within the ken of even unsophisticated laymen. A few of these suggest themselves. The usual reason for creating a family trust is the diminution of the grantur's surtaxes by the segregation of part of his property. But the normally: prudent grantor, who realizes that family solidarity may be wealiened by the development of opposing points of view between parent and child, and perhaps even between husband and wife, does not place the bulk of his property in trust; he retains more than he segregates. Therefore, he keeps the whip hand since his wife and children still depend on his pleasure as to the largest part of their prospective inheritance. Thus, even disregarding the effect of ties of blood and affection, it is cuntrary to normal human conduct to assume that the beneficiaries of a family trust will use the income which they receive contrary to the grantor's desires, that they will seek the protection of the courts if the grantur abuses such powers as he may have retained in an ostensibly fiduciary capacity, or that they will refuse to exercise powers granted them whenever the grantor so requests. Undoubtedly, the introduction of the phrase "substantial adverse interest" into Sections 166 and 167 of the Revenue Act is largely responsible for an unrealistic approach to this question, since in determining whether such an interest exists the courts have limited themselves to a consideration of that part of the grantur's property in the trust sub judice. It is submitted that an analysis of all

B. T. A. 994 (1940). Such reserved powers habitually exclude a diversion ui corpus or income to the grantor himself in order to escape the impact of $\$ 166$ and 167 . Sce note 1 supra. The fact that retention of such a power does not render trust income taxable to the grantor under $\S 166$ [Knapp v. Hoey, 104 F. (2d) 99 (C. C. A. 2d, 1939)] is immaterial when construing $\$ 22(\mathrm{a})$. Commissioner v. Buel, $120 \mathrm{~F}$. (2d) 775 (C. C. A. 2d, 1941). Similarly, where managenent of corpus is coupled with the right to dispuse thereof by will, the Clifford rule has been held applicable: Reginald B. Parsons, 44 E. T. A. 1142 (1941); but not where only the latter power is present: Lady Marian Bateman, 43 B. T. A. 69 (1940), on appial C. C. A. 1st: Walter S. Halliwell, it L. T. A. 740 (1941) ; Mary W. Pingree, 3 C. C. H. 1941 Fed. Tax Serv. $\{7600$ (B. T. A.).

117. 120 F. (2d) 775,778 (C. C. A. 2 d, 1941 ). 
the circumstances attendant on the creation of a family trust, such as the Clifford opinion calls for, should include consideration of the grantor's total wealth and that the courts and the Board should deen absence of any adverse interest in the beneficiaries of such a trust it rebuttable presumption. ${ }^{118}$ Furthermore, the possibility of the invocation of the powers of equity should similarly be considered against the background of these realities. ${ }^{110}$

Some courts have used the Clifford rationale when considering such issues. Thus in White v. Higgins ${ }^{120}$ and Cov $v$. Commissioner, ${ }^{121}$ both decided under Section 22(a), it was deemed highly improbable that a beneficiary of a family trust would ever resort to equity to restrain the discretion of the donor. The latter case also indulged in the reasonable assumption that, in view of the donor's broad reserved powers and the family relation, a trust beneficiary with a traditionally "stubstantial adverse interest" would freely give his consent to revocation of the trust. Other cases such as Fulham \%. Commissioner ${ }^{122}$ and Altmaier $v$. Commissioner, ${ }^{123}$ involving a determination of the existence of a "substantial adverse interest" within the meaning of Sections 166 or 167 or of the likelihood of resort to equity, have also adopted what may be termed the Clifford approach. ${ }^{124}$ But in Commissioner v. Prouty, ${ }^{125}$ a gift tax case, the First Circuit, although paying lip service to the realism demanded by the Clifford opinion, came to the conclusion that a husband's chances of surviving his wife with the consequent "clance to control the disposition of the entire corpus of a large estate" gave him a "substantial adverse interest." 126 It observed that the prospect of acquiring such a power of appointment would furnish a far from negligible pecuniary motive tending to induce the husband to stand out

118. Legislation providing that no "substantial adverse interest" shall be deemed to exist in a member of the grantor's family has been suggested. Ray, supra note 14, at 1358. This would seem in line with the statutory tendency to tax family units as affiliated groups of persons exemplified by $\S 24(a)(6)$ of the 1934 Act prohibiting the deduction of intra-family losses.

119. Rollins v. Helvering, 92 F. (2d) 390 (C. C. A. 8th, 1937). Cf. Commissioner v. O'Keeffe, 118 F. (2d) 639 (C. C. A. 1st, 1941) ; Lolita S. Armotr, 41 B. T. A. 777 (1940); Ray, supra note 14, at 1356.

120. $116 \mathrm{~F}$. (2d) 312 (C. C. $\Lambda .1 \mathrm{st}, 1940$ ).

121. 110 F. (2d) 934 (C. C. A. 10th, 1940), cert. denied, 311 U. S. $60 /$ (1940).

122. 110 F. (2d) 916 (C. C. A. 1st, 1940).

123. 116 F. (2d) 162 (C. C. A. 6th, 1940), cert. denicd, 312 L. S. 706 (1941).

124. See also R. Douglas Stuart, 42 B. T. A. 1421 (1940).

125. $115 \mathrm{~F}$. (2d) 331 (C. C. A. 1st, 1940).

126. It is true that the husband, if he survived, would also gain discretionary power to invade the corpus for his own maintenance, support and welfarc. But curiously cnough the court pays scarcely any attention to this factor and for its decision in finding a "substantial adverse interest" relies almost entirely on the rather odd reasoning mentioncd in the text. 
against any desire of the wife-grantor to revoke the trust. This, it is submitted, is false realism. ${ }^{12}$ Is it likely that Mr. Prouty would auction off the exercise of his power of appointment to the highest bidder among possible beneficiaries? The suggestion is preposterous, but how otherwise can the phrase "a pecuniary motive" be interpreted? The court conceded that the case was "on the border line" but stated that it cutld not be persuaded, in view of the aggregate of the husband's interests. that the Board had erred in its conclusion that he had a "sthstantial adverse interest." "128

\section{Interrelation of Gift and Incoare Tax}

In the few cases which have raised the issue courts have differed in their willingness to extend the effects of the Clifford rule to the gift tax field. In Commissioner $v$. Prout $y^{129}$ the question was whether a transfer in trust became a completed gift in 1931 (no gift tax being then in effect) when the settlor modified her power of revocation and amendment by making it dependent on the consent of her husband, or in 1935 when she finally relinquished all reserved power. If the husband had a "substantial adverse interest" the grantor gave up her unfettered power in 1931 rendering the gift complete in that year. We have seen that the court refused to accept the Government's argument that his interest was not substantial. But the Commissioner also argued that, regardless of any such interest in the husband, Mrs. Prouty in 1931 retained st

127. Some judges doubt whether the "realities" can be determined objectively. Thus, Judge Goodrich has said: "Our problem is to appraise the trust instrument against a background of realities to determine whether the grantor retained the cuntrolling hand over something he has seemed to give away.' . . . The issue is of the type, not unfamiliar in the law, where the distinctions are not black and white, but of varying shades of gray and where the shade chosen by the court will seem 'realistic' tu him whose side wins and artificial or fanciful to the other." Commissioner v. Dravo, 119 F. (2d) 97, 94 (C. C. A. 3d, 1941).

128. Perhaps the key to this decision lies in the increasing unwillingness of appellate tribunals to interfere with conclusions, however styled (i.c., as "findings of ultimate fact" or "conclusions involving a mixed question of fact and law." See Paur, Feverur Esture axd GrFt Taxatiox (1941) $\$ 14.22$ ) reached by administrative buards or commissions. It may be noted that the Cox, Fulham and Altmaicr decisiuns, which regarded the adverse interests involved as illusory, also represent aftirmances by the Eoard. Note, however, the suggestion that in tax cases the Bureau of Internal Revenue or the Treasury Department, rather than the Board, should be considered the "expert administrative agency." Commissioner v. Buck, 120 F. (2d) 775, 779, n. 4 (C. C. A. 2d, 1041). This contention, with reference to the determination of the chnership of trust curpus, was advanced by the Government in the Cliffurd case. Nash, supra nute 14 , at $194, n$. 149. Judge Frank's suggestion as to the role of the Board scems at variance with Mr. Justice Brandeis', set forth in IVilliamsport Wire Rope Cu. v. United States, 277 U. S. $551,562-65$ (1928).

129. 115 F. (2d) 331 (C. C. A. 1st, 1940). 
large a "bundle of rights and powers" that she remained the owner of the corpus and taxable on its income under the Clifford doctrine, and that a gift regarded as incomplete for income tax purposes should be similarly regarded for purposes of the gift tax. The court, doubting the applicability of the Clifford rule to the income of this particular trust, declared that gift and income taxes were not so closely integrated as to require a holding that no gift tax was payable on the creation of at trust, because under the Clifford rule the grantor remained taxable on its income. Yet it seemed dissatisfied with this conclusion for it "frankly recognized" that the interrelation of various taxes presented ptizzling problems worthy of legislative attention. ${ }^{130}$

It is submitted that not only fairness to the taxpayer but logical symmetry as well demand that no gift tax be exacted on a transfer so incomplete as to leave the transferor for income tax purposes owner of the corpus. The Government should not be permitted to eat its cakc and have it too. The Clifford concept of ownership should be considered when determining whether a transfer is sufficiently complete to rencler. it subject to gift tax and a decision on that issue should be deemed res judicata on the question of the income tax liability of the transferor. Conversely, if a court decides that the income of incompletely transferred property remains taxable to the donor, even though it is actually paid to another, then the donor should be deemed to remain owner of the property for purposes of future gift or estate taxation.

Although such integration of the several taxes was reftsed by the Board in Ellsworth B. Buck ${ }^{131}$ and in Estate of Giles W. Mead, ${ }^{132}$ both decided before the Clifford case, the Second Circuit has, subsequently to the Clifford decision, evidenced a tendency toward harmonization. In the Buck case the Board, relying primarily on the Second Circuit's decision in Knapp $v$. Hoey, ${ }^{133}$ had held that a reserved non-beneficial ${ }^{134}$ power to change the beneficiaries of trust corpus or income dicl not under Sections 22(a), 166 or 167 render that income taxable to the settlor. The dissent had urged that harmonious application of the several sections of the Revenue Act required a contrary holding, becattse under Supreme Court decisions reservation of such a power precludes the transfer from being regarded as a complete gift subject to gift tax ${ }^{1015}$

130. Similarly, Herzog v. Commissioner, 116 F. (2d) 591 (C. C. A. 2d, 1941), as to the gift and estate taxes. See Warren, Corrclation of Gift and Bstatc Tarr's (1041) 55 Hakv. L. Rev. 1.

131. 41 B. T. A. $99(1940)$.

132. 41 B. T. A. 424 (1940). See (1941) 54 Harv. L. Rev. 892.

133. $104 \mathrm{~F}_{-}$(2d) 99 (C. C. A. 2d, 1939).

134. That is, a power which cannot be exercised for the benefit of the grantor or his estate. Possession of such a power would bring $\S 166$ and 167 into play.

135. Estate of Sanford v. Commissioner, 308 U. S. 39 (1939). 
and keeps the property within the ambit of the estate tax. ${ }^{136}$ In the Mead case the Board held (1) that the gift became complete and subject to gift tax when the power to change beneficiaries was abanduned, but (2) that prior payments of trust income were not gifts from the settlor-donor to the beneficiary (and hence not subject to gift tax) because under Knapp a. Hoey such income was not taxable to the suttlur. If the latter was not regarded for tax purposes as having received the income, how, inquired the majority, could he be said to have made a gift thereof to the beneficiary? The dissent, again restating the arguments it had advanced in the Buck case, continued to regard taxation of the income to the settlor under these circumstances as a necessary corollary to the propositions laid down by the Supreme Court with respect to the incidence of the gift and estate taxes. The Secund Circuit, leaning heavily on the Clifford and Horst opinions, reversed ${ }^{137}$ the Buard's decision in the Buck case with regard to the donor's taxability on trust income. While conceding that the court was bound by Knapp a. Hocy with respect to the application of Sections 166 and 167, it deemed that case of no assistance when construing Section 22(a). It would seem to follow that the payments of trust income discussed in the Mead case should likewise be considered for purposes of taxation as having lieen received by the settlor and hence the subject of a gift from him to the beneficiary. Hence the Board's decision in the Mcad case would no longer seem to be good law. And so the recent interpretation of section 22 (a) has done yeoman service in straightening out at least sume uf the tangled interrelations between gift and income taxes. ${ }^{139}$

\section{Assignment of Income Caspis}

As stated at the beginning of this article, the Suprente Court duringr its recent terms did not restrict the interpretation of Section 22(a) to deflection-of-income situations involving the creation of certain types of trusts. In the Horst. Eubank and Schaffuer decisions, it alsu greatly

136. Porter v. Commissioner, 288 U. S. 436 (1933). The renunciatiun of such a nower will consummate the transfer which will at that time become subject to giit taw. But since the donor has thereby divested himself of the property completely, no estate tax will be due barring some peculiar circumstance such as a renunciation made in contemplation of deatl.

137. Commissioner v. Buck, 120 F. (2d) 775 (1941).

138. This vexatious subject, however, may be expected to plague all parties until the Supreme Court speaks. E.g., it is quite conceivable that the incume of the "secund trust" discussed in Welch v. Paine, $120 \mathrm{~F}$. (2d) $141,1+4$ (C. C. A. 1st, 1441), shunuld bis deemed taxable to the settlor-trustee because of his reserved cuntrol wer its disposition; yet all parties concerned in that case assumed that gifts had been made and the only issue presented to the court was the proper calculation of the taxable "net giit."." 
limited the types of assignments available for decreasing the assignor's taxable income. ${ }^{139}$

In Lucas v. Earl ${ }^{140}$ and Burnet $\%$. Leininger, ${ }^{141}$ decided about a decade ago, assignments of future income had been held taxable to the assignor, but in both of these cases, involving respectively the assignor's salary and his income from a partnership, prospective earnings had been the subject of the assignments. But when cases arose where receipt of income assigned did not depend upon "continued activities of the transferor," 142 such as doing work which entitled him to receive the salary or getting the business on which partnership profits depended, there was conflict in the decisions. Though the Second Circuit, ${ }^{143}$ ultimately followed by the Sixth, ${ }^{144}$ adopted the theory that assigned income remained taxable to the assignor only when its receipt was conditioned on his continued efforts, several other circuits held assigned future income taxable to the assignor even where his right to receive it had become irrevocably fixed prior to the time of assignment. ${ }^{145}$

This conflict was resolved in Helvering $v$. Horst ${ }^{146}$ where a gift by a donor on the cash receipts basis of detached interest coupons, delivered to the donee during the donor's taxable year and later in the same year paicl at maturity, was held to constitute realization of income by the donor taxable within Section 22(a). The Court, speaking through Mr. Justice

139. Helvering v. Horst, 311 U. S. 112 (1940); Helvering v. Eubank, 311 U. S. 122 (1940); Harrison v. Schaffner, 312 U. S. 579 (1941). In these cases the subject matter of the transfer or gift was not the property which produced the income, but the income itself. That there is no clear-cut distinction between the two situations is evidenced by the fact that in many cases the Government has argtted that the settlor of a trust should be held taxable both because of retained control over corpus and becatuse his transfer in trust was in effect a mere assignment of future income. Sce, c.g., Elizabeth K. Lamont, 43 B. T. A. 61 (1940) ; Dunlevy T. Milbank, 41 B. T. A. 1014 (1940); Jessie W. Donahue, 44 B. T. A. 329 (1941) ; Mary W. Pingree, 3 C. C. H. 1941 Fed. Tax Serv. $\{7660$ (B. T. A.) ; and the Government's briefs, filed in Commissioner v. Branch, 114 F. (2d) 985 (C. C. A. 1st, 1940) ; Helvering v. Achelis, 112 F. (2d) 929 (C. C. A. 2d, 1940); Commissioner v. Richter, 114 F. (2d) 452 (C. C. A. 3d, 1940). See also PAUL, op. cit. supra note 14 , at 273 , n. 365 .

140. 281 U. S. 111 (1930).

141. 285 U. S. 136 (1932).

142. Shanley v. Bowers, 81 F. (2d) 13 (C. C. A. 2d, 1936).

143. See, e.g., Lowery v. Helvering, 70 F. (2d) 713 (C. C. A. 2d, 1934); Rossmoore v. Commissioner, 76 F. (2d) 520 (C. C. A. 2d, 1935); Matchette v. Helvering, 81 F. (2d) 73 (C. C. A. 2d, 1936).

144. Commissioner v. Ross, 83 F. (2d) 18 (C. C. A. 6th, 1936). Sec also Hall v. Burnet, 54 F. (2d) 443 (App. D. C. 1931), cert. denicd, 285 U. S. 552 (1932).

145. Parker v. Routzahn, 56 F. (2d) 730 (C. C. A. 6th, 1932), ccrt. dcnicd, 287 U. S. 606 (1932) ; Bishop v. Commissioner, 54 F. (2d) 298 (C. C. A. 7 th, 1931); Van Meter v. Commissioner, 61 F. (2d) 817 (C. C. A. 8th, 1932).

146. 311 U. S. 112 (1940). Followed in Reginald B. Parsons, 44 B. T. A. 1142 (1941). See (1941) 41 Cot. L. Rev. 340, (1941) 39 Mich. L. Rev. 495, (1940) 18 Texas L. Rev. 478, (1941) 89 U. of PA. L. Rev. 532, (1941) 27 VA. L. Rev. 394, (1941) 19 Texas L. Rev. 489. See Van Sciver v. Rothensies, 122 F. (2d) 697 (C. C. A. 3d, 1941). 
Stone, stated that an owner of bonds acquired an economic gain when he obtained the legal right to demand payment of interest and the power to command its payment to others. But, the Court continued, not all economic gain is taxable income; "realization" of income, rather than the acquisition of the right to receive it, has always been deemed the taxable event under the revenue laws. And "realization" is usually not deemed to occur until income is paid. But receipt in cash or property has never been held the only manner in which a taxpayer even on the cash receipts basis (as Mr. Horst was) can realize income. Realization may occur "when the last step is taken by which he obtains the fruition of the economic gain which has already accrued to him."117 The taxpayer's enjoyment of the income may be consummated by some event such as making "such use or disposition of his power to receive or control the income as to procure in its place other satisfactions which are of economic worth."148 It has long been held, as the Court pointed out, that if a taxpayer procures payment of income directly to his creditors, he does not escape taxation because he did not actually receive the money. ${ }^{149}$ Similarly, Section 166 prevents such escape if he sets up a revocable trust with income payable to the objects of his bounty. ${ }^{160}$ In these situations the Court has held that it makes no difference whether the taxpayer collects the fruits of his labor or investment and uses them to procure the satisfaction of his desires, or whether he achieves the same result by disposing of his right to collect such income. The Court then applied this reasoning to the case before it and pointed out that although Mr. Horst by transferring the coupons precluded any possibility of collecting them himself, he nevertheless procured payment of the interest as a valuable gift to a member of his family. Such procuring of a satisfaction obtainable only by the expenditure of money or property, the Court continued:

"would seem to be the enjoyment of the income whether the satisfaction is the purchase of goods at the corner grocery, the payment of his debt there, or such non-material satisfactions as may result from the payment of a campaign or community chest contribution, or a gift to his favorite son. . . . The enjoyment of the economic benefit accruing to him by virtue of his acquisition of the coupons is realized as completely as it would have been if he had collected the intercst in dollars and cxpended them for any of the purposes named." 151

147. 311 U. S. 112,115 (1940).

148. Id. at 116 .

149. Citing Old Colony Trust Co. v. Commissioner, 279 U. S. 716 (1929); Bowers v. Kerbaugh-Empire Co., 271 U. S. 170 (1926); United States v. Kirby Lumber Co., 284 U. S. 1 (1931).

150. Citing Corliss v. Bowers, 281 U. S. 376 (1930).

151. 311 U. S. 112, 117 (1940). 
The latter part of this reasoning seems to speak on the conceptual plane of constructive receipt, which imports actual payment of the income to the taxpayer's designee. Such a theory seems preferable to the one which may, perhaps, be inferred from other parts of the opinion, namely, that the exercise of the power to dispose of the income, the act of assigning it, is "the last step . . . taken by which he obtains the fruition of the economic gain which has already accrued to him."162 Mr. Horst presumably experienced "such non-material satisfaction as may result from . . . a gift to his favorite son" from the moment when he presented his offspring with the coupons. Yet this disposition of income which is payable in the future clearly is not the event which caused the incidence of the tax. For if the obligor should unexpectedly default on the interest it is hardly conceivable that the Government would seek to collect an income tax from the assignor. Of course, it may be said that in such a case the "non-material satisfaction" was wholly illusory and hence should be disregarded. But does this rationalization comport with the realities? Suppose that in January a fond parent assigned to his favorite son a note due in the following December from a wholly solvent obligor who, however, had become hopelessly insolvent by the time the due date rolled around; and suppose further that the parent died a month after making the assignment. Obviously the quantum of "non-material satisfaction" he experienced under these circumstances was not affected in the slightest degree by the fact that the son never realized on the note. ${ }^{153}$

The Court also held that the taxpayer's reliance on Blair v. Commissioner $^{154}$ was not well taken. In that case, involving an assignment of a share of the life interest in a certain trust, the Court regarded the

152. Id. at 115. Indeed, the Government so argued in Annie A. Colby, 3 C. C. H. 1941 Fed. Tax Serv. $\llbracket 7741$ (B. T. A.).

153. Of course, cases where the assignments were made years before the income was received, such as the Earl and Eubank cases, show that the assignor's tax liability does not accrue until the year when the income is actually paid. But it is stubmitted that it is not alone the exercise of the power to dispose of income which consummates the as signor's enjoyment and that "realization" does not occur when he takes "the last step . . . by which he obtains the fruition of the economic gain which has already accrued to him." Resulting payment to the donee (or, at any rate, to some one, for conceivably the donee may have made a reassignment) is an indispensable factor. This is clearly stated later in the Horst opinion where the Court says that whether or not the rendition of services by the assignor is required to make the assignment effective (as in the Earl and Leininger cases) "it is the exercise of the power of disposition of the interest or compensation with the resulting payment to the donee which is the enjoyment by the donor of income derived from them." (italics supplied). Because of the mentioned difficulties inherent in the concept of a "non-material satisfaction" it seems morc satisfactory to think in terms of constructive receipt when secking to state a wholly convincing rationale for the decision.

154. 300 U. S. 5 (1937). 
right to income from the trust property as so identified with the equitable ownership that it viewed the transaction as an outright gift of income-producing property rather than as an assignment of income. In the Horst opinion the Court explains:

"Unlike income... derived from an obligation to pay interest or compensation, the income of the trust was regarded as no more the income of the donor than would be the rent from a lease or a crop raised on a farm after the leasehold or the farm had been given away." 155

When such an analogy is used to buttress a distinction which spells a property interest out of a right to receive trust income and thereby attaches different tax consequences to an assignment of such income than to assignments of rights to receive interest or salary or commissions, the Court may be regarded once again as placing reliance on "attenuated subtleties" or "niceties of the law of trusts" held of no consequence in the Earl and Clifford cases for purposes of the revenue laws.

It may be that the patent artificiality of this distinction caused Mr. Chief Justice Groner, when concurring in Huber v. Helecring, ${ }^{1 * 0}$ to disregard its restatement in the Horst opinion and to conclude that the Horst case and its companion, Helicring v. Eubank, ${ }^{15 \pi}$ had made the rule in the Blair case no longer controlling. The majority in the Huber decision, however, took a contrary view and, when considering an assignment made by a person entitled, during his life, to receive income from a trust, found a significant distinction between an assignment of part of such income for all of the assignor's life (the Blair situation) and one of all of such income for a limited period of time (one year in the Huber case). In the latter situation the assignor was held not to have given up any of the property or estate from which he derived income since "his reversionary interest is much greater than the interest the assignee received." 168

That the majority was right in treating the rule in the Blair case as a factor still to be reckoned with was soon confirmed when the Supreme Court decided Harrison $v$. Schaffner, ${ }^{150}$ the final important decision at its last term involving Section 22(a). This case involved an anticipatory

155. 311 U. S. 112,119 (1940).

156. 117 F. (2d) 782 (App. D. C. 1941).

157. 311 U. S. 122 (1940) (assignment of fully earned renewal commissions). Followed in Helvering v. Knapp, $121 \mathrm{~F}$. (2d) 454 (C. C. A. 2d, 1941); Francis T. Whitworth, 3 C. C. H. 1941 Fed. Tax Serv. $\llbracket 7606-C$ (B. T. A. mem.); Duran v. Commissioner, 4 P. H. 1941 Fed. Tax Serv. $\uparrow 62,982$ (C. C. A. 10th, 1941).

158. For a somewhat analogous balancing of the quantum of the estate of a reversioner against that of a trust beneficiary, see Helvering v. Elias, $122 \mathrm{~F}$. (2d) 171 (C. C. A. 2d, 1941).

159. 312 U. S. 579 (1941). See (1941) 54 Hars. L. Rev. 1405, (1941) 50 YaLE L. J. 512 . 
assignment of trust income held taxable by the court below to the assignee. The Court stated the issue to be whether, in the light of its opinions in the Horst and Eubank cases, it made any difference in the application of the revenue law that the gift was effected by such an assignment rather than by one of "interest, dividends, rents and the . like which are payable to the donor." 160 But despite this auspicious keynote the Court contented itself with avoiding the taxpayer's reliance on the Blair case by again distinguishing it as "a transfer in praesenti to the donee, of a life interest in the corpus of the trust property." 101 The Schaffner case, however, was regarded by the Court to present quite a different situation since it involved annual assignments made late in 1929 and 1930 of specified amounts of the net income of a trust for the respective subsequent years. Such gifts by a beneficiary of some part of his income derived from trust property "for the period of a day, a month or a year" were:

"no such substantial disposition of the trust property as to camouflage the reality that he is enjoying the benefit of the income from the trust of which he continues to be the beneficiary, quite as much as he enjoys the benefit of interest or wages which he gives away as in the Horst and Eubank cases." 162

This passage seems confusing. Does it mean that Mrs. Schaffner was deemed to enjoy the benefit of the trust income through the procuring of a "non-material satisfaction" because she did not make substantial disposition of the trust property? This can hardly be so, since the satisfaction arises from the disposition of future income to obtain something not otherwise procurable except by the expenditure of money or money's worth; thus disposition or retention of the income-producing property seems immaterial to the applicability of the "satisfaction" theory. To illustrate, Mr. Horst kept his property; Mrs. Schaffiner was deemed by the Court not to have disposed of hers in any substantial way; and Mr. Eubank never had any income-producing property of which to dispose. For although Eubank assigned all "right, title and interest" 163 in the contract covering his insurance renewal commissions, the Court did not mention the assignment of the contract which, therefore, presumably was not considered as "property" distinguishable from the right to income conveyed by the assignment. Eubanli assigned everything he could assign; Blair assigned only part of his future income. If the former is taxed because by the exercise of his power to command

160. 312 U. S. 579,580 (1941).

161. Id. at 582 .

162. Ibid.

163. See Eubank v. Commissioner, 117 F. (2d) 737 (C. C. A. 2d, 1940). See (1940) 53 Harv. L. Rev. 1398. 
the income he enjoys the benefit thereof, it seems unrealistic not to tar the latter for the same reason.

In the Schaffner opinion, however, the Court professed not to be troubled by the logical difficulties of drawing the line between a gift of an equitable interest in property for life effected by a gift for life of a share of the income of a trust and the gift of such income or a part of it for the period of a year. But since, on the one hand, a gift measured by the donor's life may be for thirty days or twenty years and, on the other, the Court would undoubtedly deem the Schafficr case controlling if the assignment were of two, five or even ten years' income, ${ }^{104}$ from a practical point of view the divergent tax results seem quite unjustifiable. Suppose that a taxpayer's grandfather created a trust naming him sole beneficiary during the four year period when he might be expected to need the income for his college education, the trust instrument, however, containing no restriction on use of the income. Because of family financial reverses the beneficiary decides to forego a higher education, and assigns all his interest to his widowed mother. How, logically, can the applicability of the rule of the Blair case be denied? Will the Court seek to distinguish between the equitable interest in trust property held by a life tenant and a tenant for a term of years? To draw such distinctions, it is submitted, is wholly out of harmony with the Court's present approach to tax questions.

It should be noted that in the Schaffncr case, the Court relied not only on the "satisfaction" theory of the Horst and Eubank cases, but added:

"Even though the gift of income be in form accomplished by the temporary disposition of the donor's property which produces the income, the donor retaining every other substantial interest in it, we have not allowed the form to obscure the reality. Income which the donor gives away through the medium of a short term trust created for the benefit of the donee is nevertheless income taxable to the donor [citing the Clifford and Hornel cases]. We perceive no difference, so far as the construction and applieation of the Revenue Act is concerned, between a gift of income in a specified amount by the creation of a trust for a year, see Hormel v. Helvering, and the assignment by the beneficiary of a trust already created of a like amount from its income for a year."105

This passage demonstrates the close affinity between cases where income is deflected through the medium of a trust and by means of an assignment. In the latter situation, the time factor, borrowed from

164. This assumption seems justified because the Court found no diffculty in dseming the rationale of the Clifford case, which involved a short-term trust, very possibly applicable to the ten-year trust of the Fuller case.

165. 312 U. S. 579, 583 (1941). 
the trust cases, is seized upon to furnish an analogy. There are already some lower court decisions where the power-of-disposal-over-income and the "satisfaction" concepts of the assignment cases have been used, more or less aptly, to justify taxation of income to grantors of trusts. In Whiteley $v$. Commissioner ${ }^{166}$ the settlor of certain trusts set up for his minor children was taxed on the income which he could have demanded of the trustee but only to apply to his children's support. The fact that he did not do so but left the money with the trustee for reinvestment was deemed immaterial by the court ${ }^{107}$ which maintained that "he controlled the use of the money and had the same non-material satisfaction as that of the taxpayer in the Horst case." 108 But the Horst case seems merely to hold that exercise of the power of assigning income results in a "non-material satisfaction" which otherwise could have been obtained only by the expenditure of money or money's worth. In the Whiteley case the taxpayer had long since parted with the incomeproducing property placed in the trust; he had made his expencliture of money or money's worth at that time. Should the income remain taxable to him solely because he retains the option of determining whether it shall be accumulated or spent for the benefit of the beneficiaries? If under the trust instrument there were no such option and the only use to which the income could be put were reinvestment by the trustee, clearly the settlor would not be taxable on any theory of "non-material satisfaction." Can he be deemed to have experienced such satisfaction when the trustee made the reinvestments, merely because he could have diverted the flow of the money? Possibly his rather limited control over the income may be a basis for taxing it to him. But it is submitted that the latent power of control and the enjoyment of a "non-material satisfaction" are not one and the same thing.

Another instance of the application of the rationale of the assignment cases to a trust income situation is found in Commissioner $v$. Buck. ${ }^{169}$ There, the settlor had reserved the right to reallocate income to any one except himself; the Second Circuit held such power highly important in determining his taxability inasmuch as the Horst and Schaffner cases had declared that the donor's power to dispose of income "is the equivalent of ownership of it." And in Mairs v. Reynolds the rationale of the Horst and Eubank cases, i.e., procuring and enjoy-

166. 120 F. (2d) 782 (C. C. A. 3d, 1941).

167. See also David M. Heyman, 44 B. T. A. 1009 (1941), where the Board said: "the possession of the power is determinative, not the fortuitous manter of its use." But cf. Helvering v. Safe Deposit \& Trust Co., 121 F. (2d) 307 (C. C. A. 4th, 1941) (estate tax; non-exercise of power of appointment).

168. 120 F. (2d) 782, 785 (C. C. A. 3d, 1941).

169. 120 F. (2d) 775 (C. C. A. 2d, 1941).

170. 120 F. (2d) 857 (C. C. A. 8th, 1941). 
ing an economic benefit of the income, was adopted as an alternative ground for holding taxable to the settlor trust income applied to the education of his children. This process of cross-fertilization may be expected to continue. ${ }^{\mathbf{1 7 1}}$

171. Yet it should be observed that the power to dispuse of income in an ascignment case and the continuing power to reallocate trust income are not quite the same thing. Anyone who has an unfettered legal right to receive income has the power of assigning it, but it is the exercise of the power which raises the question involvcd in the Horst, Eubank and Sihaffner cases. On the other hand, in the trust cases the mere existense of the power of reallocation, whether exercised or not, is under the Busl: decision sufficient reason for taxing the grantor. This distinction may seem immaterial. Assume that $A$ has a right to receive interest on $X$ bonds and on $Y^{\prime}$ bonds. He assigns the interest on the former as in the Horst case and places the latter in a trust similar to that created by Mr. Buck. Both amounts of income remain tasable to him, although in the former case he has irrevocably exercised his power of disposal of the income and in the latter has retained a continuing power to shift the income hither and yon. But suppose that $A$, in contemplation of a trip to the wilds of Tibet which may isolate him for ten years, wishes to provide against the radical diminution of his incume which, he fears, may be brought about by tax increases during his absence. His wife is wealthy in her oun right, which precludes her as donee or beneficiary of income. His thoughts, therefore, turn to his adult children. Yet he desires that during his absence she retain power over allocation of the income which he is willing to deflect, should the oceasion arise, since he deems it wise that the mother should have some check on whatever spendthriit proclivities the children may develop. So he transfers to her power for ten years to assign the interest from the $X$ bonds to whomsoever she chooses, excluding herself, and places the $Y$ bonds in a ten-year trust, naming an independent trustee with full powers of management, with income payable in equal shares to his children but with pover in the wife to reallocate the income to any one, excluding herself. Assume further that, contrary to $A$ 's gloomy forebodings, taxes are not raised, the children conduct themselves faultlessly and, consequently, the wife never exercises either power. Why is taxable during the ten years? $A$ continues to receive the income on his $x$ liunds; surcly it will continue to be taxed to him since a transfer of the power of assignment would not be countenanced as a device to shift tax incidence. With regard, however, to the power to reallocate trust income, might not a different result follow? $A$ has restrved no powers of any kind and a term of ten years is hardly of such short duratiun as to call for the conclusion. in the words of the Buck case, that "the control factor is sufficiently grecent." Indeed, the Second Circuit has recently so held in Commissioner v. Jonas, 122 F. (21) 169 (C. C. A. 2d, 1941). Therefore, the Cliffurd rule wuuld hardly be applicable to him. But Mrs. A now has that very vital incident of ownership, almost unlimited power to dispose of the income as she chooses. Should the tax nut fall on her rather than wn the children whose continued receipt of income is wholly denendent on her whim? If sw, she would be taxable on the trust income whether or nut sle exercised her putser. Is to the income which she may assign, clearly she would become tasable thercon if and when she exercised her power and assigned the same, let us sujpuse, to sume fiet charity because in so doing she would realize that "non-material satisfaction" which, as the Hors! case teaches, she could otherwise procure only by the expenditure of mon'y ar muney's worth.

"The term 'benefit', which occurs in many of the deflectiun of income cases discussed above, is also sometimes loosely used when translated from une upiniun to another without precise regard for its various connotatiuns. Compare the tylutes of "benefit" discussed in the Clifford case with those adverted to in the Hurst and Intor eases, in 


\section{CoNCLUSTON}

In conclusion, it seems quite clear that the Supreme Court and the lower tribunals have travelled far beyond the limits which an optimistic taxpayer might have thought indicated by the Clifford opinion. There the Court stated that the settlor "has rather complete assurance that the trust will not effect any substantial change in his economic position." 172 This conclusion was based on the short term of the trust, the fact that the income remained within settlor's family and the fact that the settlor retained control over investment. Will the absence of any of these factors aid the taxpayer? Apparently not. The Fuller dictum indicates and the Second Circuit's opinion in the Buck case expressly states that the settlor of a trust of long duration may be taxable, if he has retained sufficient control over the corpus or even over the disposition of the income. ${ }^{173}$ The Supreme Court's summary in the Schaffner opinion of its holding in the Clifford case omits all mention of the familial relationship. Furthermore, since in the assignment cases the identity of the donee is a matter of no consequence whatsoever, is it not oversanguine to anticipate that the Supreme Court would exempt the settlor of a trust merely because the beneficiary is not a relative ? $^{174}$ Would it not lend a sympathetic ear to an argument such as the Government made in Helvering v. Achelis, ${ }^{175}$ which ran:

"It is true that in the Clifford case the beneficiary was the wife of the grantor . . ., while in the instant case the beneficiary appears to have been a charitable or educational corporation. . . . But if, as we believe, an underlying reason for stressing the family relationship in these cases is that the courts will not countenance an arrangement whereby the taxpayer seeks to obtain indirectly a deduction for personal, living or family expenses to which he is not entitled under the law, then, surely, there is an equally cogent reason for the disapproval of cases where the taxpayer may seek to obtain by indirection a deduction for contributions in excess of the amount permitted by law. Looking at the situation realistically, there seems to be no ground for distinguishing cases where the gift is made to a member of the grantor's family, a charity or

Estate of William J. Garland, 43 B. T. A. 731 (1941), and in Margaret R. Phipps, 43 B. T. A. 324 (1940). Perhaps a meticulous distinction between these different sorts of benefits is unimportant, since all of them result in taxation of the person benefited. An outstanding authority in the tax field has observed that the concept of 'benefit' is stubtly entwined with that of 'dominion and control'. PAUL, op. cit. supra note 128, $\$ \$ 1.0 \$$ and 1.12."

172. 309 U. S. 331, 335-36.

173. See also Helvering v. Elias, 122 F. (2d) 171 (C. C. A. 2d, 1941).

174. This opinion is hazarded despite the Second Circuit's contrary holding in Commissioner v. Chamberlain, $121 \mathrm{~F}$. (2d) 765 (1941).

175. 112 F. (2d) 929 (C. C. A. 2d, 1940). 
a stranger, provided, of course, the grantor may fairly be considered the owner of the trust properties." 170

Finally, as indicated above, non-retention of control over corpus will not help where control over the disposition of the income has been reserved.

Such a reservation is fatal since, in the words of the Horst case, "the power to dispose of income is the equivalent of ownership of it." Another single factor which apparently will render the settlor taxable is the short duration of a trust with reversion to the grantor, even if there are no express reservations of control. The Second Circuit has said in the Buck case that the brevity of the term in and of itself imports control. ${ }^{177}$ A third single factor, which may prove fatal and on which the dictum in the Fuller case places sole emphasis, would seem to be retained control over the corpus itself.

Assuming that a man of property creates a 25-year trust, with income irrevocably payable to the Republican Party, and with no control of any sort reserved over the corpus, would the Court allow him to escape taxation on the trust income where, under its decisions to date, the same man would be taxable on renewal commissions payable to him for the next 25 years even though he had irrevocably assigned them to the GOP? It is hardly likely that any such situation will ever come before the Court for adjudication, but the prediction is ventured that the taxation of trust income to the settlor ${ }^{178}$ will be analogized more and more to the taxation of assigned income to the assignor.

176. Ibid. Brief for Petitioner, pp. S-9.

177. See also Commissioner v. Barbour, 122 F. (2d) 165 (C. C. A. 2d, 1941); Helvering v. Elias, 122 F. (2d) 171 (C. C. A. 2d, 1941).

178. It should be noted, however, that in cases of divided control it may be difficult to determine to whom trust income should be taxed. Assume a person about to embarl: on a risky business venture with dim forebodings of judgment creditors some years hence; with his worldly goods he creates a five-year trust precisely of the Clifford type but, as a precaution to forestall a reversion should his fears materialize, provides that his eldest son may at any time terminate the trust and acquire the corpus. Would the latter be 3 candidate for taxability on the trust income under Commissioner v. Richardson, $121 \mathrm{~F}$. (2d) 1 (C. C. A. 2d, 1941)? True, he cannot exercise any control over the corpus until he makes use of his power of termination; but "the possession of the power is determinative, not the fortuitous manner of its use." David MI. Heyman, 44 B. T. A. 1009 (1941); Whiteley v. Commissioner, 120 F. (2d) 782 (C. C. A. 3d, 1941). But of. Helvering v. Safe Deposit \& Trust Co., 121 F. (2d) 307 (C. C. A. 4th, 1941) (estate tas; non-exercise of power of appointment).

Furthermore, taxing someone other than the person who actually receives the income may, in perfectly conceivable cases, result in a danger to the revenue. Assume a paterfamilias who has made a success out of his vacuum cleaner business, his property consisting of stock therein and of outside investments. Being of an adventurous turn of mind, he contemplates risking a large part of his fortune in assisting the development of an invention related to television. Before doing so, however, he trustees his vacuum 
What loopholes are left for diminishing surtaxes by anticipatory arrangements? Under the Blair case the life beneficiary of a trust may escape taxation on all or part of the income if the assignment equals the temporal length of his estate. And an owner of property can still reallocate the income thereon among his family and escape high surtax brackets if he is willing to make outright gifts to spouse and children. But, where husband or wife is the donee, in time even that aventte of minimization may be closed, for presumably we have not heard the last of the rejected provision of the Revenue Bill of 1941 which would render mandatory the filing of a joint return by husband and wife.

cleaner shares, naming his wife and children life beneficiaries, but retaining extensive control over the corpus, and, if you will, over the disposition of the income to any one but himself. Subsequently his new venture into which he has poured all the rest of his fortune proves a dismal failure. The vacuum cleaner company, however, continues to prosper mightily. The consequent large trust income is taxable to the now penniless settlor. What price the Clifford case then? 


\section{APPENDIX}

A. Cases following the Clifford rule with little or no discussion: Penn v. Commissioner, 109 F. (2d) 954 (C. C. A. Sth, 1940) ; First Nat. Bank v. Commissioner, 110 F. (2d) 448 (C. C. A. 7th, 1940); Helvering v. Hormel, 111 F. (2d) 1 (C. C. A. 8th, 1940), remanded sub nom. Hormel v. Helvering, 312 U. S. 552 (1941); Thomson v. Helvering, 114 F. (2d) 607 (C. C. A. Sth, 1940); Helvering v. Abraham, 115 F. (2d) $36 S$ (C. C. A. 2d, 1940) ; Herbert W. Hoover, 42 B. T. A. 289 (1940), on appeal C. C. A. 6th; William J. McCormack, 43 B. T. A. 924 (1941); Maurice Jacobs, 3 C. C. H. 1941 Fed. Tax Serv. \7654-A (B. T. A. mem.).

B. Cases applying the Clifford rule to situations more faviorable to the taxpayer: Cox v. Commissioner, 110 F. (2d) 934 (C. C. A. 10th, 1940), cert. denicd, 311 U. S. 667 (1940) ; Reuter v. United States, 34 F. Supp. 1014 (Ct. Cl., 1940), ccrt. derricd, 312 U. S. 695 (1941); White v. Higgins, 116 F. (2d) 312 (C. C. A. Ist, 1940); Commissioner v. Berolzheimer, 116 F. (2d) 628 (C. C. A. 2d, 1940); Reuter v. Commissioner, 118 F. (2d) 698 (C. C. A. 5th, 1941); Commissioner v. Buck, 120 F. (2d) 775 (C. C. A. 2d, 1941); Commissioner v. Barbour, 122 F. (2d) 165 (C. C. A. 2d, 1941); Commissioner v. Woolley, 122 F. (2d) 167 (C. C. A. 2d, 1941); Helvering v. Elias, 122 F. (2d) 171 (C. C. A. 2d, 1941); Morton Stein, 41 B. T. A. 994 (1940); George H. Deuble, 42 E. T. A. 277 (1940) (in part), on appeal C. C. A. 6tlz; Purdon Smith Whiteley, 42 B. T. A. 316 (1940); Frank G. Hoover, 42 B. T. A. 786 (1940), on apfeal C. C. A. Gils; H. S. Richardson, 42 B. T. A. 830 (1940), aff'd sub nom. Richardson v. Commissioner, 121 F. (2d) 1 (C. C. A. 2d, 1941); Archibald G. Bush, 43 B. T. A. 535 (1941); Snowden Fahnestock, 43 B. T. A. 569 (1941); William L. AfcKnight, 3 C. C. H. 1941 Fed. Tax Serv. I 7271-B (B. T. A. mem.); Robert H. Cory, 3 C. C. H. 1941 Fed. Tax Serv. T) 7272-B (B. T. A. mem.) ; David M. Heyman, 44 B. T. A. 1009 (1941); Reginald B. Parsons, 44 B. T. A. 1142 (1941) (in part); Ellis H. Warren, 3 C. C. H. 1941 Fed. Tax Serv. \7721 (B. T. A.) ; Ella E. Russell, 3 C. C. H. 1941 Fed. Tax Serv. $\ 7724$ (B. T. A.).

C. Cases refusing to apply the Clifford ralc: Helvering v. Achelis, 112 F. (2d) 929 (C. C. A. 2d, 1940) ; Commissioner v. Branch, 114 F. (2d) 985 (C. C. A. 1st, 1940); Helvering v. Palmer, 115 F. (2d) 368 (C. C. A. 2d, 1940); Kent v. Rothensies, 35 F. Supp. 291 (E. D. Pa. 1940), rev'd on other grounds, 120 F. (2d) 476 (C. C. A. 3d, 1941); Commissioner v. Chamberlain, 121 F. (2d) 765 (C. C. A. 2d, 1941); Jones v. Norris, 122 F. (2d) 6 (C. C. A. 10th, 1941); Commissioner v. Jonas, 122 F. (2d) 169 (C. C. A. 2d, 1941) ; Frick v. Driscoll, 4 P. H. 1941 Fed. Tax Serv. [62,383 (W. D. P3. 1941); Stanley v. Smith, 4 P. H. 1941 Fed. Tax Serv. $\lceil 62,823$ (D. Conn. 1941); Lolita S. Armour, 41 B. T. A. 777 (1940), on appeal C. C. A. 7th; George H. Deuble, 42 B. T. A. 277 (1940) (in part); Dunlevy T. Milbank, 41 B. T. A. 1014 (1940); Edward H. Heller, 41 B. T. A. 1020 (1940); Edna B. Elias, 41 B. T. A. 1109 (1940), rev'd sib nom. Helvering v. Elias, 122 F. (2d) 171 (C. C, A. 2d, 1941); Susan Sturgis Barry, 42 B. T. A. 1 (1940); Antoinette K. Brown, 42 B. T. A. 693 (1940), renanded sub non. Commissioner v. Brown, 4 C. C. H. 1941 Fed. Tax Serv. $\{9667$ (C. C. A. 3J, 1941) ; Frank E. Wolcott, 42 B. T. A. 1151 (1940); John P. Wilson, 42 B. T. A. 1260 (1940), on appeal C. C. A. 7th; Elizabeth K. Lamont, 43 B. T. A. 61 (1940), on appeal C. C. A. 2d; Lady Marian Bateman, 43 B. T. A. 69 (1940), on appcal C. C. A. 1st; Arthur M. Betts, 3 C. C. H. 1941 Fed. Tax Serv. $\{7116-D$ (B. T. A. mem.); William J. Garland, 43 B. T. A. 731 (on rehearing, 1941) ; Jessie W. Donahue, 44 B. T. A. 329 (1941); Rose L. Ray, 3 C. C. H. 1941 Fed. Tax Serv. T7474-A (B. T. A. mem.); Reginald B. Parsons, 44 B. T. A. 1142 (1941); John N. Fulham, 44 B. T. A. 1183 (1941) ; Estate of William Childs, 44 B. T. A. 1191 (1941); Frederick Ayer, 3 C. C. H. 
1941 Fed. Tax Serv. $\{7683$ (B. T. A.). See also John R. MacMants Trust, 44 B. T. A. 508 (1941), where a taxpayer sought application of the rule on the theory that four beneficiaries were the grantors of an amended trust and that hence the undistributed income was taxable to them in four equal parts rather than to the trustee in 10 lo.

D. Cases using Clifford rationale in cognate fields:

(1) Assigmment of income: Huber v. Helvering, 117 F. (2d) 782 (App. D. C. 1941); Harrison v. Schaffner, 312 U. S. 579 (1941).

(2) Section 166: Fulham v. Commissioner, 110 F. (2d) 916 (C. C. A. 1st, 1940); Helvering v. Dunning, 118 F. (2d) 341 (C. C. A. 4th, 1941); R. Douglas Stuart, 42 B. T. A. 1421 (1940).

(3) Section 167: Altmaier v. Commissioner, 116 F. (2d) 162 (C. C. A. Gth, 1940), cert. denicd, 312 U. S. 706 (1941); Rand v. Helvering, 116 F. (2d) 929 (C. C. A. 8th, 1941).

E. Cases refusing to extend Clifford rationale to other fields: Commissioner v. Park, 113 F. (2d) 352 (C. C. A. 3d, 1940) ; Commissioner v. Prouty, 115 F. (2d) 331 (C. C. A. 1st, 1940); Otto Peterson, 42 B. T. A. 102 (1940); Mary W. Pingree, 3 C. C. H. 1941 Fed. Tax Serv. $\llbracket 7660$ (B. T. A.).

F. Cases remanded to board for consideration of applicability of Clifford rule: Hormel v. Helvering, 312 U. S. 552 (1941) ; Helvering v. Richter, 312 U. S. 561 (1941); Commissioner v. Ward, 119 F. (2d) 207 (C. C. A. 3d, 1941); Commissioncr v. O'Keeffe, 118 F. (2d) 639 (C. C. A. 1st, 1941) ; Commissioner v. Central Nat. Bank, 119 F. (2d) 470 (C. C. A. 6th, 1941); Commissioner v. Brown, 4 C. C. H. 1941 Fed. Tax Serv. If 9667 (C. C. A. 3d, 1941). 